Nova Southeastern University NSUWorks

\title{
Organization For Collection Development in Medium-sized Academic Libraries
}

\author{
Carol W. Cubberley \\ Nova University, car23cubb@yahoo.com
}

This document is a product of extensive research conducted at the Nova Southeastern University College of Engineering and Computing. For more information on research and degree programs at the NSU College of Engineering and Computing, please click here.

Follow this and additional works at: https://nsuworks.nova.edu/gscis_etd

Part of the Computer Sciences Commons

\section{Share Feedback About This Item}

\section{NSUWorks Citation}

Carol W. Cubberley. 1987. Organization For Collection Development in Medium-sized Academic Libraries. Doctoral dissertation. Nova Southeastern University. Retrieved from NSUWorks, Center for Computer-Based Learning. (473)

https://nsuworks.nova.edu/gscis_etd/473.

This Dissertation is brought to you by the College of Engineering and Computing at NSUWorks. It has been accepted for inclusion in CEC Theses and Dissertations by an authorized administrator of NSUWorks. For more information, please contact nsuworks@nova.edu. 
ORGANIZATION FOR COLLECTION DEVELOPMENT

IN MEDIUM-SIZED ACADEMIC LIBRARIES

Carol W. Cubberley, B.Ed., M.S.I.S.

NOVA UNIVERSITY

1987 


\section{Nova University \\ Center for Computer-Based Learning}

I certify that I have read and am willing to sponsor this Major Field Project (MFP) submitted by Carol W. Cubberley. In my opinion, it conforms to acceptable standards and is fully adequate in scope and quality as a Major Field Project for the degree of Doctor of Arts at Nova University.

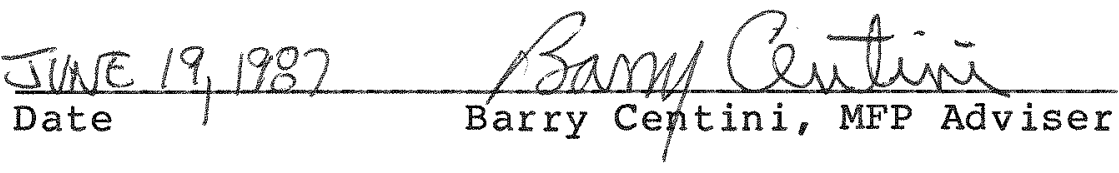

This Major Field Project was submitted to the Central Staff of the Center for Computer-Based Learning of Nova University and is acceptable in partial fulfillment of the requirements for the degree, of Doctor of Arts.

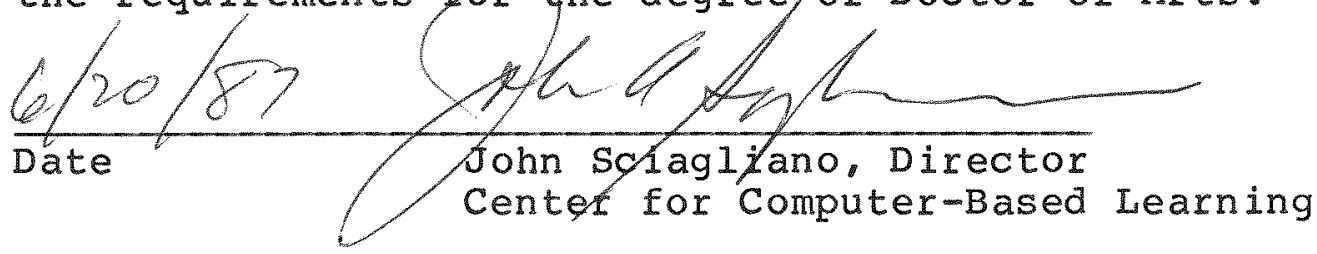

I certify that I have read this document and in my opinion it conforms to the acceptable standards for a Major Field Project for the degree of Doctor of Arts at Nova University.

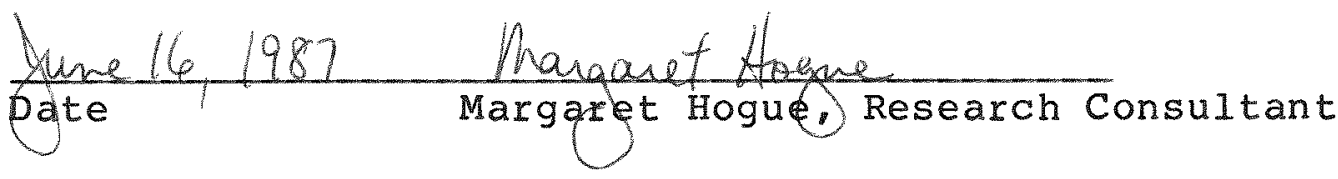




\section{ABSTRACT}

At the University of Central Florida Library, the librarians with collection development assignments, and the Head of Collection Development, were frustrated in their attempts to fulfill their responsibilities. Those librarians did not report to the Department Head, but to other departments, and only a small percentage of their time was set aside for collection development. This meant that collection development duties Erequently were deferred to other duties. There also was uncertainty about what duties could be expected of these librarians. Some functioned only as liaisons to academic departments, while others did extensive selection of material, wrote collection development policies, and evaluated collections and their use. A survey of medium-sized academic libraries was conducted to ascertain their organizational structure for collection development, and what effect that structure has on the activities performed. Two survey 
instruments were developed. One was sent to chief collection development officers. That survey asked questions about organizational type, time spent on collection development, patterns of fund allocation, and staff size. The other survey was for completion by collection development librarians, or librarians with collection development responsibilities. Five copies of that survey were sent to each selected institution. Librarians were asked about their job assignments, time spent on collection development, their qualifications, faculty participation, and priorities. Both questionnaires included a list of sixteen collection development activities. Respondents were asked to indicate which activities were desirable, and which ones they had done. Responses were received from 46 of 71 libraries surveyed. The study revealed that librarians defer collection development to other responsibilities and perform few of the activities they feel are desirable for collection development. Many are selecting materials for the collection without having collection development policies or collection 
evaluations to refer to. Most feel adequately well prepared to do collection development, but many felt they did not have sufficient time for it. Although few libraries of the size studied had separate collection development departments, the librarians in those that did spend more time on collection development, were less likely to defer collection development to other activities, and performed more collection development activities than their colleagues in other types of libraries. It was recommended that a library of this size that is serious about collection development locate librarians with primary assignments in collection development in departments established for that purpose. These librarians should have subject expertise, and sufficient time to write collection development policies, evaluate collections, and conduct circulation studies and user surveys. Further study of the results of the various types of organization for collection development are needed. 
I would like to thank all those who participated in this study: the Iibrarians at the University of Central Florida Library who helped me refine the questionnaires, and the librarians in the participating libraries who took time to respond. Without their cooperation, the data collection would have been impossible. I appreciate their candidness, their promptness, and their interest as expressed in their added comments.

Members of the faculty at Nova University have provided much needed guidance, advice, and patience. My thanks to Dr. Barry Centini, Dr. George Barton, and Dr. John Scigliano. It has been both exciting and frustrating to be a pioneer with them in the use of the electronic classroom. My local reader, Margaret Hogue, has been a pleasure and an inspiration to work with. Her expertise and knowledge of academic libraries were especially helpful. The Director of Libraries at the University of Central Florida, Anne Marie Allison, 
provided me the support I needed to complete this degree while employed there. My thanks to her and to my immediate supervisor, Orlyn LaBrake.

Two family members deserve my special thanks for their material and moral support. They are my mother, Hilda Boothe Weir, and my husband, Bill. My mother has encouraged and supported me all my life in anything I ever attempted. She made a trip to orlando to help me prepare the survey.

Bill is everything a husband should or could be. No one could be more encouraging, supportive, or patient. He has made many sacrifices for the sake of my work at Nova. 
TABLE OF CONTENTS

Chapter

Page

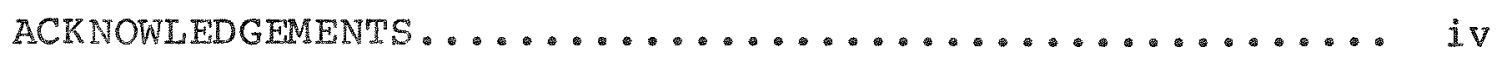

I. INTRODUCTION

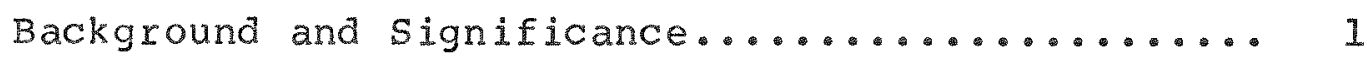

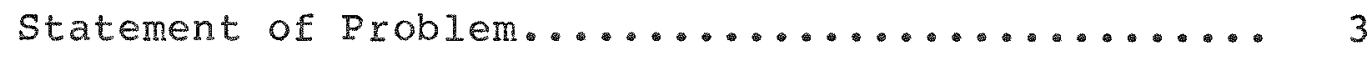

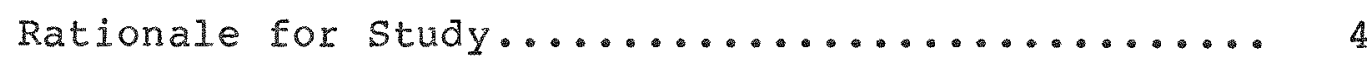

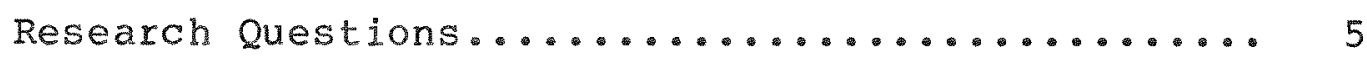

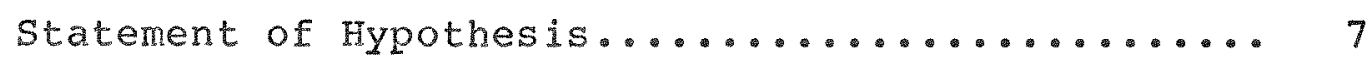

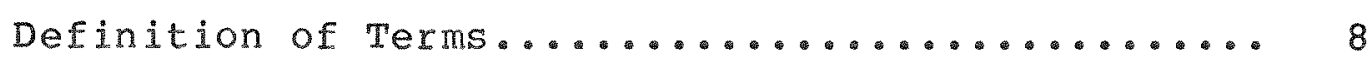

II. REVIEW OF RELATED LITERATURE

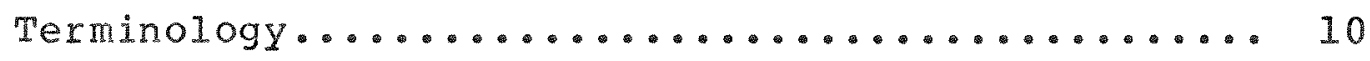

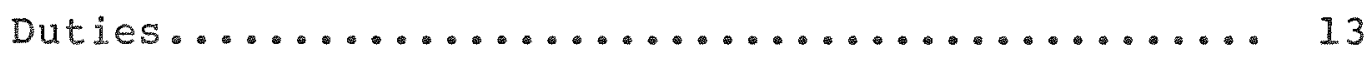

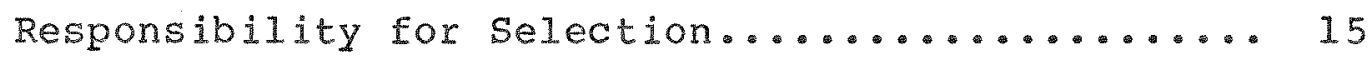

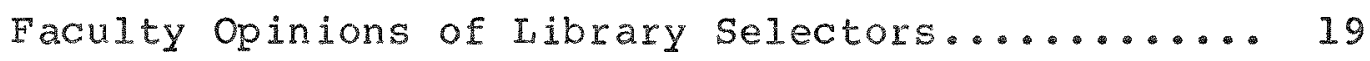

Weeding and Discontinuation of Titles.......... 20

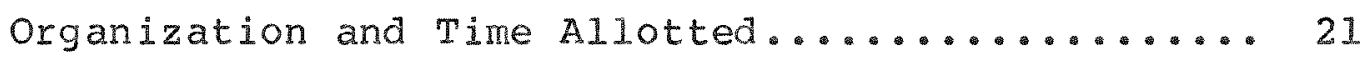

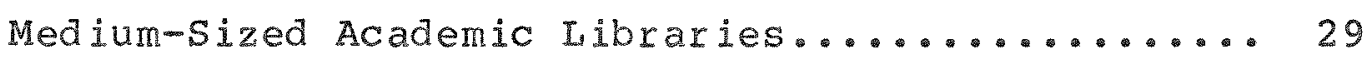

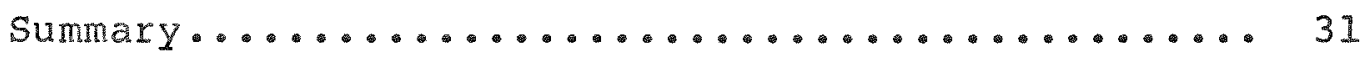

III. PROCEDURES AND METHODOLOGY

$-v i \dot{i}-$ 


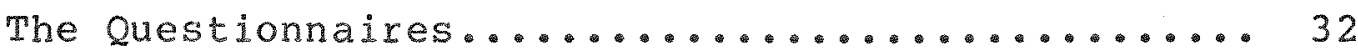

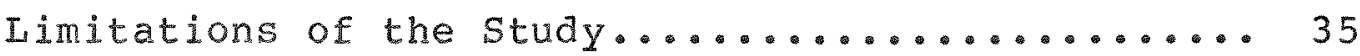

IV. PRESENTATION OF RESULTS

Questionnaire for Chief Collection Development

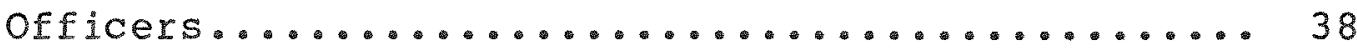

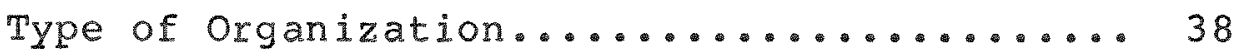

Time Spent on Collection Development...... 42

Library staff size.................. 44

Allocation of Funds................ 47

Collection Development Activities......... 48

Questionnaire for Librarians with Collection

Development Responsibilities........... 56

Librarians" Assignments............. 57

Priority of Collection Development........ 60

Librarian Qualifications for Collection

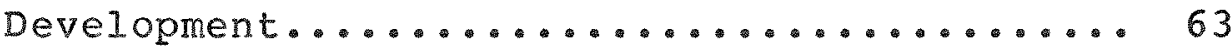

Faculty Participation in Collection

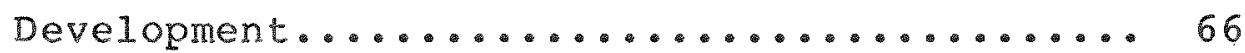

Time Spent on Collection Development...... 67

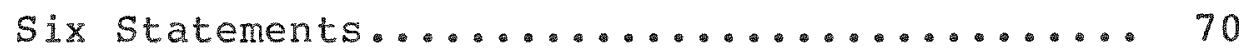

Collection Development Activities......... 73 
V. SUMMARY AND CONCLUSIONS

Answers to Research Questions.............. 81

General summary...................... 84

The Collection Development Policy............ 87

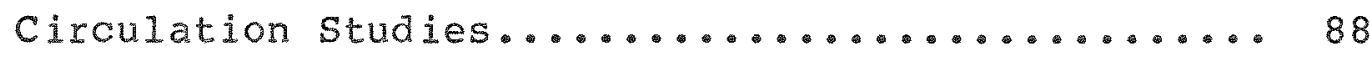

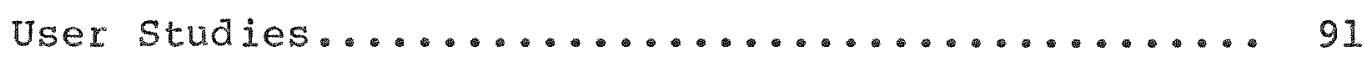

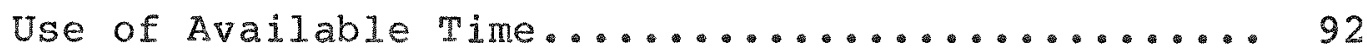

Recommendations for Implementation............ 93

Further Research Needs.................... 96

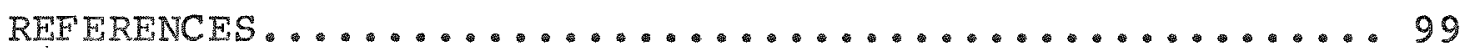

APPENDIX A. Cover Letter Sent with Questionnaires..... 106 APPENDIX B. Questionnaire for Chief collection

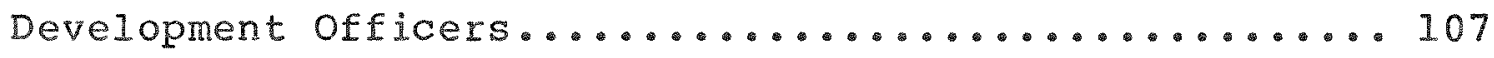
APPENDIX C. Questionnaire for Librarians With

Collection Development Responsibilities............. 109 APPENDIX D. Librarian Job Titles.................. 11

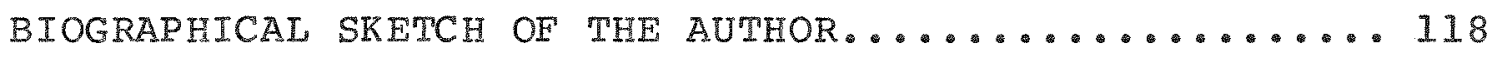


1. Organization for Collection Development.........4.

2. Expected Percentage of Time Spent on

Collection Development by Library Type......... 41

3. Actual Percentage of Time spent on

Collection Development by Library

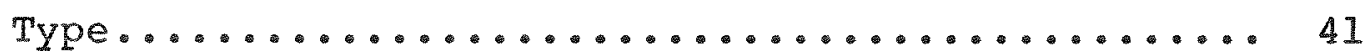

4. Full Time Equivalent Librarian Positions........ 45

5. Full Time Equivalent Librarians Assigned to

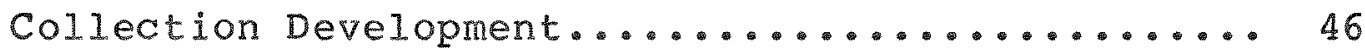

6. Fund Allocation Patterns in Three Library Types...4 48

7. Desirability and Expected Accomplishment

of Sixteen Collection Development Activities..... 50

8. Desirable and Expected Collection Development

Activities Comparison Between Library Types...... 56

9. Assignments of Iibrarians with Collection

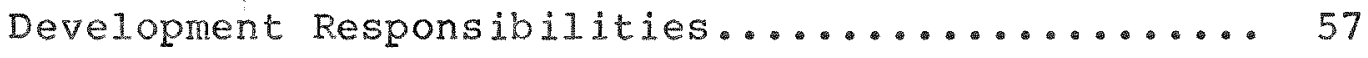

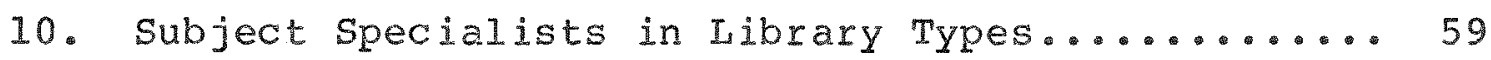


11. Activities Listed as Having Priority

Over Collection Development................6 60

12. Priority of other Responsibilities

Over Collection Development by Library Type...... 63

13. Qualifications for Collection Development

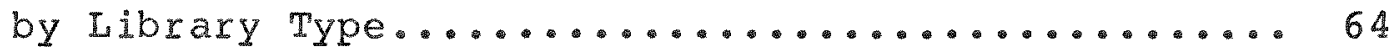

14. Faculty Interest and Participation in

Collection Development..................67

15. Expected and Actual Time Spent on

Collection Development in Three Library Types..... 68

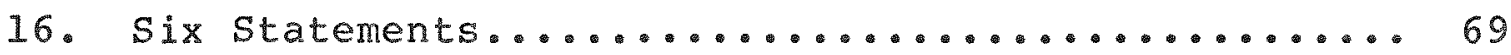

17. Relationship Between Advanced Subject

Education and Perceptions of Faculty Respect

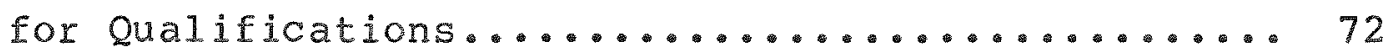

18. Sixteen Collection Development Activities

Rated as Desirable and Accomplished by

Collection Development Librarians............ 74 
Chart

1. Percentage of Desirable Activities

Accomplished in All Libraries Responding........79

2. Percentage of Desirable Activities

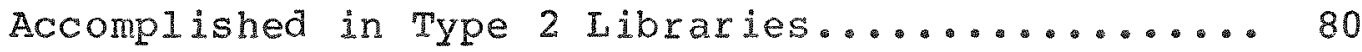


CHAPTER ONE

Introduction

\section{Background and Significance}

Librarians with collection development responsibilities at the University of Central Florida frequently experienced frustration as they sought to fulfill their professional responsibilities. Although one librarian had been appointed Head of Collection Development, and as many as fifteen others had collection development responsibilities, the duties had not been clearly defined.

The Head of Collection Development was responsible for determining the materials to be purchased or accepted as gifts and added to the collection, an intellectually demanding, professional task (7). All the librarians with collection development assignments were members of other departments, and none reported directly to the Head of Collection Development. The 
amount of time they were expected to devote to this activity suggested that it was not a high priority for the library administration. This in turn affected the performance of the librarians, and it was feared that many books were being added to the collection that should not be, while others that should be purchased were being missed.

Conversations with colleagues and articles in the professional journals showed that the problems of organization for collection development and the priority accorded it were widespread in academic libraries. While collection development frequently is described as a principal responsibility of librarians, it is a descriptor that has come into common use only in the past forty years. It has not found its organizational niche in the way cataloging or reference service have. This is especially true in academic libraries, where, until the mid-1940s, teaching faculty held almost exclusive book-selecting prerogatives (6). 
Statement of Problem

A primary problem, apparently the result of organizational uncertainty, was that of deferring collection development activities. Typical of assignments was the one made at the University of Central Florida to the liaison for the College of Business. This college had six departments: Accounting, Economics, Finance, Hospitality Management, Management, and Marketing. There was a real estate institute attached to the college as well. The librarian given this assignment was expected to devote ten percent of her time to communication with six faculty representatives, writing or revising collection development policies, reviewing books received on approval, revising the approval profile if needed, and wisely spending part of the book budget.

Since it has not been established if this amount of time is more or less than adequate to perform these tasks (8), it was impossible to know if this librarian should be expected also to evaluate the use of the collection, do user studies, and manage the physical 
preservation of the collection. What was known was that the librarian's physical and administrative presence in the reference department meant that she would be pressured to devote less than ten percent of her time to collection development. The all too obvious and urgent daily demands in reference eroded that time and it never was recovered.

Librarians at the University of Central Florida Library had stated that collection development required flexibility and blocks of time not available to them within the prevailing organizational structure. Ten percent of a forty hour week is four hours, but the intricacies of scheduling reference desk duty. bibliographic instruction, and professional meetings never left a block of time that size. Moreover, although a few librarians had as much as fifteen percent of their time assigned to collection development, others had as little as five percent.

Rationale for Study

Because of these problems, it seemed desirable to 
conduct a survey of other institutions of comparable size and mission to discover how they were organized for collection development, and what effect, if any, that organization had on the performance of collection development duties. An attempt would be made to discover if some of these libraries were organized in ways that allowed the librarians to devote the time expected to their collection development duties. If such an organizational model could be identified, it was hoped that the data collected would persuade administrators in libraries of this size to consider the possibility of installing a type of the model in their libraries.

\section{Research Questions}

Research questions posed were:

1. Is there a prevalent organizational model in medium-sized academic libraries?

2. Does the organizational model affect the way collection development is done?

3. Do libraries of this size typically allocate funds 
for faculty expenditure, or retain control of them?

4. What relationship is there between fund allocation and amount of librarian time spent on collection development?

5. Are librarians with collection development responsibilities typically administratively assigned in public services or technical services?

6. What relationship is there between administrative assignment of librarians and the amount of time spent on collection development?

7. What relationship is there between administrative assignment of librarians and the collection development activities they perform?

8. Do librarians defer collection development to other duties?

9. How are librarians academically or experientially prepared to do collection development?

10. Do librarians feel adequately prepared educationally for their collection development responsibilities? 
11. Do librarians feel that faculty respect their qualifications and judgment?

12. What tasks do librarians feel are appropriate or necessary for collection development?

13. How many of these tasks do they perform?

\section{Statement of Hypothesis}

The organizational structure of the medium-sized academic library affects collection development activities. When collection development is recognized as a separate activity, and a permanent department is established for its performance, the effect will be positive. Collection development librarians in these libraries will accomplished more of these duties deemed desirable by themselves and their supervisors than will their colleagues in libraries without separate departments for collection development. Conversely. librarians with collection development responsibilities who work in libraries where collection development is not recognized as a separate activity, or where it does not have a permanent, fulltime department established 
for its accomplishment, will be negatively affected. They will accord other responsibilities priority over collection development, and will not accomplish many of the tasks identified as desirable.

Definition of Terms

A liaison is a librarian with responsibility for communicating with faculty, other liaisons, or librarians in other libraries, in a particular subject area or areas. Liaison with faculty typically includes conveying budget and deadline information; notification concerning publications of interest: conferring on large purchases and deletions; cooperative writing of collection development policies, receiving order requests, and soliciting curriculum and research information.

Medium-sized academic library is a library serving a university with some graduate programs, but lacking research status. Professional librarians number between eighteen and thirty, and the annual materials budget is $\$ 800,000$ or more. 
A collection development librarian is one who has collection development as a primary responsibility. The term librarian with collection development responsibilities is used when those duties are combined with others and are secondary. All other terminology used has standard definitions. Reference may be made to The ALA Glossary of Library and Information Science. 
CHAPTER TWO

Review of Related Literature

A review of the literature shows some areas of concern addressed repeatedly by authors and researchers. There is confusion about terminology for librarians engaged in collection development. This confusion is related to uncertainty about the role of the collection development librarian. A frequent topic of discussion is responsibility for selection. Some assert that librarians are responsible, while others advocate leaving this task to the teaching faculty. Related to this is the question of librarian liaison work with teaching faculty. Other subjects frequently discussed are library organization for collection development and the amount of time to be spent on this activity.

Terminology

The terms most frequently encountered to describe these librarians are bibliographer and subject 
specialist. Dickinson uses the terms bibliographer. subject specialist, and librarian selector

interchangeably (16). Sloan comes to no conclusion about terminology to describe these librarians (32). Writing more recently, Sohn uses the term collection development librarian to refer to the person in charge of collection development, and selector to refer to librarians with responsibilities in this area (34). Bryant refers to them as collection development officers and collection developers respectively (10). The term subject specialist is widely used in Great Britain, where most academic librarians have honors degrees in academic subjects but seldom have formal training in library techniques (18). Even so, Woodhead, writing in Great Britain, expresses concern about terminology, suggesting subject librarian or subject responsibility (38). The term bibliographer has been widely used in the United States. This term usually implies a narrower span of duties than does the term collection development librarian.

It is bibliographers who are most often accused of $-11-$ 
elitism. Bibliographers are seen as working in isolation, selecting titles that build an ideal, balanced collection in one subject. They are not perceived as having to concern themselves with users' demands, shelf availability, acquisitions or cataloging problems, or any of the other mundane but compelling problems their colleagues face. Bibliographers of this type have been and are found in very large research libraries with large budgets. As budgets shrink, and publication continues to increase, they may be disappearing (16).

In this country, too, there is disagreement on terminology. Dickinson uses the term subject specialist to discuss what has been described above as bibliographer. Haro uses the term bibliographer to describe a librarian who performs all professional tasks in a given subject, including not only reference and collection development, but technical services tasks such as cataloging and acquisitions, too (22). 


\section{Duties}

What, then, are the duties of collection development librarians? Reference and cataloging are excluded as being clearly outside the scope of duties. Tuttle, in refuting Haro, advocates the use of materials selectors who guide the growth of library collections, but does not list specific duties (36). Dickinson states that an important part of the job is collection evaluation and retrospective buying. He feels that since there is not enough money for retrospective buying in most libraries, these positions should be abolished. He suggests that the money saved by abolishing positions be spent for books and restoration (16). He does not suggest who will decide what to buy or what to restore, or who will be responsible for collection evaluation.

Sohn, in a survey conducted of Association of Research Libraries members, found that the librarans were almost always expected to perform selection and provide liaison links to the teaching faculty. Assignments also frequently included collection 
evaluation, specialized reference assistance, online searching, preservation decisions, and specialized bibliographic instruction (34).

The authors most helpful in defining tasks are Parker and Carpenter, and Ricking and Booth. Parker and Carpenter used a zero-based budgeting concept to justify staff levels and assignments. Librarians in the reference department of the Iibrary they studied had forty-five percent of their time allocated for collection development responsibilities. Twenty collection development activities were identified. These were grouped in broader areas that include liaison work, policy development, evaluation, selection, allocations, and acquisition functions. When listed in priority order, liaison was considered most important, Fifth in importance but first in time spent was selection. Also considered important were writing policies, evaluation of collections, and work with other libraries. Further down the list were acquisitions tasks and collection maintenance ( 30 ).

The work of Ricking and Booth is in the 
theoretical realm, but they identify similar tasks for the Collection Development Subsystem. These are the Collection Information Module (evaluation, liaison): the Collection Planning Module (policy, allocations); Library Materials Selection Module; and Offerings Evaluation Module (bulk purchases, standing orders, gifts) (31).

Specific activities are listed for professional, technical, and clerical staff for collection development. For the professional, these include user surveys and evaluation of patterns of materials use; tasks not included in Parker and Carpenter. The task of searching the library catalog is assigned to technical personnel by Ricking and Booth. Bryant contends that most experienced collection development librarians prefer to do at least some of this themselves, because of the information they gain about the collection (8).

Responsibility for Selection

An area of controversy is the matter of 
responsibility for materials selection. In the past forty years, several circumstances have combined to decrease faculty participation in, and increase librarian responsibility for, selection of books and other materials. These include increased faculty specialization, faculty responsibility for larger class loads and advising, faculty committee work and community service (32), and the "publish or perish" syndrome. Increased specialization has affected the ability of faculty to select in broad subject areas. while the other factors have made serious inroads on the time available to them for selection.

At the same time, librarians have been growing in professionalism and educational preparation (18). Many have second master's degrees in subject areas. They may be expected to have the bibliographic expertise and the access to the tools of collection development needed to acquire materials consistent with meeting the goals of the parent institution.

Although there is agreement that the trend in academic libraries is toward librarian responsibility 
for selection, there is no consensus that this trend is desirable. Dickinson states that library service and effectiveness have been declining during the years librarians have been doing more selection, and makes a correlation, unsupported by data, between the two phenomena (16). Tuttle admonishes librarians to rely on the specialization of the faculty, thus implying that the primary responsibility does lie with the librarian (36).

Danton advocates participation by interested faculty, with final responsibility remaining in the library, since it is accountable for the use of its funds (14). Curley and Broderick offer arguments both for and against librarian responsibility for selection (13). They point out that faculty frequently have neither the time nor interest to do an adequate job of selecting library materials.

Although some argue that librarians do not have the subject expertise of faculty, Curley and Broderick point out that faculty also do not have adequate knowledge of their colleagues' fields, and so may do no 
better than librarians in selecting for them. That is, if they do not neglect them altogether. Because librarians bring more balance and objectivity to the task, Curley and Broderick advocate librarian responsibility, with the caveat that they take pains to know their communities.

Gardner also believes that librarians are more likely to take a broad area of the collection into consideration, while the faculty member's interest may be limited to a narrow area (21). Messick advances the idea that selection naturally passes from the faculty to the librarian when the library reaches a certain stage in its growth. When that stage is reached, faculty selectors more and more frequently have their requests returned because they already are on order or in the library, and so they begin to rely more on the librarian selectors (27).

In her survey, Sohn asked what degree of control the teaching faculty had over both selection of materials and allocation and expenditure of library funds. She found that in research libraries, 
responsibility for allocation was retained almost solely in the library, that expenditure of funds was largely controlled in the library, and that selection of materials was shared with faculty (34).

In spite of disagreements about the final responsibility for ordering, all writers agree that liaison work is of primary importance and that librarians ignore faculty expertise and interest to their peril. Baatz writes to this issue, pointing out that a persistent theme in this debate is the complaint of librarians that faculty will not participate in spite of numerous opportunities (5). For this reason, librarians are left the responsibility by default, if not by choice.

Faculty Opinions of Librarian Selectors

Once faculty have been relieved of collection development responsibilities, the question remains, are they satisfied with the selection done by librarians, and with the library in general? Woodhead found that in British academic libraries, subject specialists had 
not been warmly received, in spite of their honors degrees in subject areas (38). Haro finds faculty opposition decreasing, with a growing willingness to be relieved as long as the librarians are qualified (22). Batz maintains that faculty are overwhelmed with other responsibilities, and are satisfied so long as the librarians do a good job (5). As Smith points out, the librarian's:

work must be judged on the degree to which he fulfills his overall charge, and the best indicator of this is, frequently, clientele or colleague evaluation (33).

Weeding and Discontinuation of Titles

The areas that faculty are most reluctant to trust to librarian decision making are weeding and discontinuation of journal titles. Stueart found that librarians and faculty disagreed significantly, not only on who should make the final decision in weeding, but on whether weeding is even necessary or desirable (35). Sloan found, however, that librarians were very 
concerned about their relationship with faculty (32), and thus are unlikely to forge ahead with weeding or cancellations without consultation. Batz found that decisions about cancellations of serials were more likely to result in faculty/librarian consultation than any other (5). Because of inflation and budget cuts, cancellation of journal titles is an activity that many libraries have engaged in during recent years. Conversely, understaffing has made it impossible for many libraries to consider systematic weeding projects. Nonetheless, faculty sometimes are so nervous about library weeding they imagine it has occurred even when it has not (37).

Organization and Time Allotted

Since it appears inevitable that collection development will be the responsibility of the librarians in large and medium-sized academic libraries, the next questions raised are: How will the librarians be organized for collection development, and how much time will be devoted to it? Although there is 
no doubt that there should be a reference department, and that reference is a public service, and that there will be a cataloging department in technical services, collection development is organizationally ill-defined. Is it a public service, a technical service, or neither? Is it a function of acquisitions or reference, or is it a separate function best placed in a separate department?

The American Library Association places its Collection Management and Development Section in the Resources and Technical Services Division (2). But many academic libraries place collection development under the assistant director for public services. In research libraries, Sohn found that 14 percent of those libraries had placed collection development in public services (34). If there is a separate assistant director for collection development, this person frequently lacks a staff, but must depend on the part-time attention of members of the reference department (26). Osburn found consistency where no one else does, saying: 
Usually, collection development is the responsibility of an administrative officer of the library ... who delegates authority on a subject basis among a number of librarians with specialized training and interests (28). But Haro in 1967 and Bryant in 1986 found that there was no clear model of organization for collection development. Haro, in a survey of seventy academic libraries of all sizes, found selectors in reference departments, in acquisitions departments, and in separate collection development departments.

Sloan characterized collection development as a "boundary spanning activity; that is as an activity that requires many transactions across interorganizational and intraorganizational boundaries" (32).

She identified three organizational designs for collection development. Type 1 does not recognize collection development as a separate activity, but one that takes place in already established departments with other purposes, such as reference or acquisitions. 
Type 2 recognizes collection development as a separate activity, and creates a department to administer it. Type 3 draws staff from other departments on a temporary basis to perform collection development activities. In this model, the staff members' primary responsibilities and loyalties are to the parent unit. Sohn found that in half of the libraries she surveyed, the collection development officer had line responsibility for the selectors (34). These libraries, all large research institutions, would correspond to the type of library sloan identified as Type 2.

Futas claims that public services librarians make up the majority of selectors for academic libraries and asserts that this is as it should be. Reference librarians, she writes, know what is asked for, what is in other libraries, and what should be purchased for their own collections (20).

Parker and Carpenter, however, in describing a library that accomplishes collection development from within the reference department, question whether this 
model is best. They advocate an examination of traditional patterns and a review of assumptions (30).

Howard draws on contemporary organization theory to support her assertion that there is no one best way to organize. Variables of environment, resources, technology, type of task, and type and size of library must be considered (24). Sloan also does not advance any of her three types as preferable, but states that in the absence of a "best way," output becomes increasingly important (32).

Bryant discusses an organizational pattern that corresponds to Sloan's Type 3, calling it a "selection posture" (10, p. 116). She asserts that librarians in this structure probably will emphasize liaison work, possibly with the generation of a collection devlopment policy. Her "collection management and development posture" corresponds to Sloan's Type 2. This structure, she admits, is extremely labor intensive. The range of responsibilities is expanded to include evaluation, preservation, liaison work with other libraries, and specialized reference and instruction 
work.

If there is no best way to organize for collection development, it is a curious fact that in libraries organized in the ways Sloan describes as Type 1 and Type 3, collection development often seems to be the task neglected when time constraints apply. This may be due in part to the fact that much of collection development activity is an independent activity. difficult to measure and quantify. As Dickinson says. other duties require more coordination and control. Thus the unstructured and "unbusy looking" activities of collection development create conflict and pressure to perform other activities that are more obviously immediately productive and therefore more easily justified and evaluated (16).

Bryant (10) and Osburn (29) both have discussed this issue. Osburn points out that an "invisible" collection development organization, such as a Type 1 or Type 3, is easily raided when unexpected demands are made on librarians time. Bryant points out that when insufficient time is available for collection 
development work, the result may be unwise purchases. Parker and Carpenter identify other pressures that contribute to the delay of collection development activities. These include the immediate and obvious demands for reference service and bibliographic instruction (30). Both Bryant, and Parker and Carpenter, complain about the difficulty of determining the amount of time it takes to do collection development, Bryant calling for research to establish formulas for assigning human resources in different subjects (8).

Ferguson and Taylor, in an analysis of activities of public services librarians, found that even librarians who were called subject specialists devoted almost twice as much time to reference as to collection development. Public services librarians with collection development duties listed not only reference, but professional development and attending meetings as having priority over acquisitions (19).

Haro found that subject bibliographers in the reference department received no reduction in the hours 
they were required to spend at the reference desk. He believes that having this type of organization results in conflicts and problems of administrative control (23). Messick also advocates an administratively separate department so that the primary work is not diluted by demands from other departments (27).

If Type 1 and Type 3 organizational models result in neglect of collection development, it is in libraries organized in a Sloan Type 2 model that charges of elitism are heard. Collection development librarians conferring with faculty colleagues, reading reviews and professional journals, evaluating collections, and conducting user studies, are performing tasks that seem unstructured and are not quantifiable. They may be envied by other librarians. These other librarians are assigned to the reference desk at set hours, are expected to teach a certain number of classes, catalog a certain number of books, or conduct a certain number of online searches. Baatz, in visits to seventeen Association of Research Library libraries, found elitism to be among the problem areas 
(5). Smith defends collection development librarians, saying:

If they do, as some have charged, represent an elite in academic librarianship, it is an elite that more than pays its own way through quality service and hard work (33).

Bryant suggests that reactions to charges of elitism may be one of the reasons libraries, even those organized as Type 2, now frequently give collection development librarians part-time assignments in other departments (10).

Medium-sized Academic Libraries

Notable for its absence from the literature is a common definition of the term medium-sized academic library, although it is a term frequently used. Ferguson defined a medium large centralized university library as one of around 1.5 million volumes (19). Bryant based her definition on materials expenditures, using in $1974 / 75$ the range of $\$ 325,000$ to $\$ 465,000$. This would exclude members of the Research Libraries 
Group and most major state institutions (9).

DeVilbiss, in an article that includes the phrase "medium-sized academic library" in the title does not define the term, but is referring to California state Polytechnic University at Pomona (15). This library is listed in the current American Library Directory as having a professional staff of thirteen and a materials budget of slightly over $\$ 1,000,000$ (3). On the basis of staff size, it was excluded from this study. The American Library Association sponsors, within its Resources and Technical Services Division, discussion groups for Chief Collection Development Officers of Large Research Libraries, and for Chief Collection Development Officers of Medium-Sized Research Libraries. The first group is open to the chief collection development officers of the first forty university libraries listed in the Association of Research Libraries annual statistical report (2).

The second is open to the research libraries not included in the top forty. 


\section{Summary}

A review of pertinent literature showed ongoing concern with the terminology used to describe librarians responsible for collection development, and with the assignment of responsibility for this task to librarians or teaching faculty. Attention also is frequently given to the individual tasks included within the assignment "collection development". Authors also discuss the different ways libraries can be organized for collection development, and the problems of deferring collection development responsibilities to other more immediate demands. It cannot be said that there is a consensus of opinion on any of these topics. However, all agree that consultation and cooperation between librarians and faculty are essential. 
CHAPTER THREE

Procedures and Methodology

The Questionnaires

Two survey instruments were developed, designed to discover how medium-sized academic libraries were organized for collection development: what specific duties collection development librarians had; what ones they accomplished: whether they were satisfied with the arrangement; what qualifications they had; the degree of faculty participation; and whether they perceived the faculty as being satisfied with the arrangement. One questionnaire was designed for completion by chief collection development officers [Appendix B], and the other for collection development librarians or librarians with collection development responsibilities [Appendix C]. Drafts of the questionnaires were distributed to ten librarians in a medium-sized academic library with explanations of the information meant to be elicited by each question. These librarians reviewed the questionnaires and made 
suggestions for rewording and rearrangement. Revisions were made as a result of these suggestions.

The final versions of the questionnaires were duplicated on colored paper. Yellow was used for the "Questionnaire for Chief Collection Development Officers" and blue for the "Questionnaire for Librarians with Collection Development Responsibilities." This color coding was intended to facilitate the tabulation of responses. When necessary in this paper to distinguish between the questionnaires, they will be referred to as Questionnaire \#1 (for chief collection development officers), and Questionnaire \#2 (for librarians with collection development responsibilities.)

The libraries to be surveyed were selected from the American Library Directory 39th edition (3). All academic libraries listing a professional staff of between 18 and 30 librarians were selected as being most comparable to the institution being studied, with 23 professional positions. Seventy-one libraries fitting this description were discovered. 
Each qualifying library was sent one copy of Questionnaire \#1, and five copies of Questionnaire \#2. Also included were a cover letter [Appendix A] and six stamped, addressed envelopes for return of the surveys. It was hoped that an envelope for each survey would encourage participation, as it made it unnecessary for one person to collect and return the completed surveys. Such an arrangement also protected the privacy of respondents.

Responses were received from 47 libraries $(66$ percent), but three of these responded with Questionnaires \#1 only, and three with Questionnaires \#2 only. Full sets of one Questionnaire \#1 and at least one Questionnaire \#2 were received from 41 libraries ( 57 percent). All questionnaires could be used to analyze some questions. But in some instances, cross tabulations were done between questionnaires, and in these instances, incomplete sets could not be used. One library that responded with a Questionnaire \#I only was in the process of reorganization. It appeared that the chief collection development officer had just been 
appointed, and that collection development librarians were to be appointed soon.

Limitations of the study

Because of the large number of libraries surveyed, no follow-up by mail or telephone was attempted. Follow-up might possibly have increased the number of responses, and obtained Questionnaires \#1 when they were not received from libraries that returned Questionnaires \#2. Telephone inquiries could also have clarified some responses on some questionnaires.

For instance, sloan had the libraries she surveyed placed in organizational categories by independent judges, based on information supplied by the libraries (32). In this survey, respondents were asked to categorize their organizational type themselves, with no background information supplied. Not all libraries fit neatly into one of the three described categories, and an independent judge might possibly have placed some libraries in categories different from those chosen by the participants. 
Another point of confusion was the question asking for the number of full time equivalent librarians on the staff. This question apparently was unclear to many respondents. When the question was unanswered, the number of professional librarians listed for that library in the American Library Directory was used. Although medium-sized academic libraries, as defined by the author, were surveyed, a number of respondents indicated that they were located in branch libraries. Librarians in branch libraries often are the only professional in that branch, and so have responsibilities that differ greatly from those of their colleagues in libraries with 18 or more librarians. The responses of those librarians might have affected the results.

Iibrarians were asked to state their job title or assignment. It would have been useful if they also had been asked what department they resided in. Chief collection development officers also should have been asked for their titles and what other responsibilities they had. Those two questions would have aided the 
investigator in resolving questions of library organizational type in some instances.

On Questionnaire \#1, chief collection development officers were asked how much time was spent and expected to be spent on collection development They were given ranges of responses to select from. On Questionnaire \#2, librarians were asked how much time they spent and were expected to spend on collection development. They were given blank lines to fill in with any amount. More meaningful analysis and comparisons of the responses would have been possible if the response format had been the same on both questionnaires, preferably that used on Questionnaire \#2. 
CHAPTER FOUR

Presentation of Results

Questionnaire for Chief Collection Development Officers

\section{Type of Orqanization}

The first question on Questionnaire \#1 established the type of organization for collection development as defined by Sloan:

In Type I designs, acquisitions, allocation of funds and selection are dispersed among several larger functional units within the library. Typically, in Type I's, allocation and monitoring of funds takes place within the acquisitions or technical services unit where materials are procured, while selection of materials is carried out within public service units. The distinguishing characteristic of Type II designs is that collection development is recognized as a distinct activity and a separate collection development unit is created. Responsibility for the activities which comprise collection 
development is assigned to a member of the top management of the library as a principal or sole responsibility. Type III designs are also characterized by the recognition that collection development is a distinct activity. Responsibility for collection development in Type III designs is, as in Type II designs, vested in a member of the library's top management. Type III designs are distinguished from Type II designs by the formation of a temporary, rather than a permanent, collection development unit. The members of this temporary unit are specialists drawn from various functional departments within the library. They assemble to perform collection development activities and then return to their regularly assigned departments (32, p. 84).

Sloan, after personal visits to the libraries in her study, described the organization and submitted her descriptions to three judges, who designated each as Type 1, Type 2, or Type 3 (32, p. 85).

In the present study, the three types were 
described, and the respondents asked to choose the designation that most nearly matched the organization of their library. In Table 1 the results of the categorizations are displayed. Not all libraries fit neatly into one of the three types, but all respondents checked one of the three responses, although a few wrote notes indicating that their library did not fit precisely into a category. Of 43 libraries, more than half (23) were Type 3, with 16 more saying they were Type 1. Only five identified themselves as Type 2 organizations.

When she did her study of research libraries in 1973, Sloan found four libraries of Type 1, five of Type 2, and only two of Type 3. In this study, Type 3 was found to be the more prevalent type of organization in medium-sized academic libraries, with Type 2 being unusual. It is assumed that the difference is a result of staff size, but further study might reveal a difference in the importance ascribed to this activity by administration. 
TABLE 1

ORGANIZATION FOR COLLECTION DEVELOPMENT

\begin{tabular}{|l|c|c|}
\hline Type of Organization & Iribraries (1) & Respondents (2) \\
IType 1: Within Larger Unit & 16 & 70 \\
Type 2: Permanent Separate Unit & 5 & 14 \\
Type 3: Temporary Separate Unit & 23 & 105 \\
\hline
\end{tabular}

(1) Questionnaires \#1

(2) All questionnaires

TABLE 2

EXPECTED PERCENTAGE OF TIME SPENT ON COLLECTION DEVELOPMENT BY LIBRARY TYPE

\begin{tabular}{|c|c|c|c|c|c|}
\hline Type of organization & $0-108$ & $11-258$ & $26-508$ & $51-758$ & $76-1008$ \\
\hline Type 1 & 6 & 3 & 5 & 1 & 0 \\
\hline Type 2 & 0 & .25 & 1.25 & 1.25 & 2.25 \\
\hline Type 3 & 9.5 & 5.5 & 2.5 & .5 & \\
\hline Totals & 15.5 & 8.75 & 8.75 & 3 & 3.25 \\
\hline
\end{tabular}

TABLE 3

ACTUAL PERCENTAGE OF TIME SPENT ON COLLECTION DEVELOPMENT BY LIBRARY TYPE

\begin{tabular}{|c|c|c|c|c|c|}
\hline Type of organization & $0-10$ & $11-25$ & $26-50$ & $51-75$ & $76-100$ \\
\hline $\begin{array}{ll}\text { Type } & 1 \\
\text { Type } & 2 \\
\text { Type } & 3\end{array}$ & $\begin{array}{c}7 \\
0 \\
12.5\end{array}$ & $\begin{array}{l}5 \\
.25 \\
4.5\end{array}$ & $\begin{array}{l}2.5 \\
\frac{1}{0} \cdot 25\end{array}$ & $\begin{array}{l}.5 \\
1.25\end{array}$ & $0^{.25}$ \\
\hline Totals & 19.5 & 9.75 & 3.75 & 3.75 & .25 \\
\hline
\end{tabular}


Time Spent on Collection Development

The chief collection development officers were asked to state a percentage of time librarians were expected to spend on collection development. Many respondents had difficulty responding to the question, as expectations vary for different librarians within the same library. Some checked more than one response, and one checked all responses. Some did not check any range, indicating that expectations cannot be expressed as percentages in their organizations. In Table 2, the results of the responses are displayed.

It appears that less time is expected to be devoted to collection development by individual librarians in libraries of Type 1 and Type 3. Even though the range $0-10$ percent was not selected by any Type 2 libraries, it still was the range with the most total selections, all from Types 1 and 3 libraries. Forty-two percent of the chief collection development officers expected the librarians involved in collection development to devote 10 percent or less 
of their time to it, and 65 percent expected less than 25 percent. In contrast, on the Questionnaires \#I from Type 2 libraries, two respondents indicated that librarians were expected to spend more than 76 percent of their time on collection development, another marked 51-75 percent, and another, 26-50 percent, with 50 percent circled. The fifth stated that eight librarians were involved in collection development, with assignments in all ranges except the lowest. Chief collection development officers were asked to estimate the percentage of time actually spent by librarians on collection development activities. The responses, displayed in Table 3 , are similar to the responses to the second question. Because of the use of ranges in the responses, the results, when compared to responses to Question 2, are inconclusive. Of 37 respondents replying, seven (19 percent) selected a lower range of number for time spent than for time expected. All the rest selected the same range for both questions.

The questionnaire revealed that many librarians do 
not have specific assignments with priorities or percentages attached to them. However, the author knows of at least one instance, in a library that does have annual "Letters of Assignment", where assignments have been rewritten during an academic year because other duties encroached so much on collection development that it had to be removed.

On a questionnaire from a Type 3 library, the response 76-100 percent was marked. It seems strange that librarians who nominally are in another department would be expected to or would spend more than 50 percent of their time on collection development. The three librarians from that library who returned Questionnaires \#2 listed their time spent as 50 percent, 20 percent, and 25 percent respectively.

\section{Library Staff Size}

Respondents were asked to indicate the number of full time equivalent librarians on their staffs. Staff levels were somewhat lower than those reported in the library directory used to select the libraries 
surveyed. Although not all respondents commented, some indicated that they had unfilled positions and were reporting filled positions only. The results are displayed in Table 4.

\section{TABLE 4}

FULI TIME EQUIVALENT LIBRARIAN POSITIONS

IN MEDIUM-SIZED ACADEMIC LIBRARIES

\begin{tabular}{|l|l|l|}
\hline Library Type & Mean & SD \\
Type $1 \mathrm{n}=16$ & 21.4 & 3.32 \\
Type 2 $\mathrm{n}=5$ & 22.1 & 3.88 \\
Type 3n=23 & 21.4 & 4.19 \\
\hline
\end{tabular}

Although staff sizes in all libraries ranged from 14 to 29 librarians, staff size seems to have no bearing on how the libraries are organized. The means for Types 1 and 3 libraries are the same, and Type 2 libraries add, on average, only one half of a librarian position. This suggests that establishing a separate department for collection development may be more dependent on administrative commitment than number of positions available.

Responses, displayed in Table 5, to the question 
"What is the full time equivalent of librarian time assigned to collection development activities?" revealed little difference between Type 1 and Type 3 libraries.

TABLE 5

FULL TIME EQUIVALENT LIBRARIANS

ASSIGNED TO COLLECTION DEVELOPMENT

\begin{tabular}{|l|l|l|}
\hline Library Type & Mean & SD \\
Type $1 \mathrm{n}=13$ & 2.48 & 1.88 \\
Type 2 $\mathrm{n}=3$ & 5.33 & 1.15 \\
Type 3 $\mathrm{n}=19$ & 2.46 & 1.10 \\
\hline
\end{tabular}

The average for 35 responses to the question was 2.73 FTE librarians. Type 2 libraries, however, assigned an average of 5.33 FTE librarians to collection development, while Type 1 assigned 2.48 and Type 3, 2.46. Because the number of usable responses from Type 2 libraries was so low, caution must be used in interpreting the results. However, it may be pointed out that these libraries, based on the evidence in Table 3, were working with staffs of essentially the 
same size, yet the Type 2 libraries assigned twice as many positions to collection development.

\section{Allocation of Funds}

In order to ascertain if libraries of the size being surveyed were retaining control of their book funds or relinquishing them to teaching faculty, chief collection officers were asked to respond to the question, "Does your library allocate money to academic departments for expenditure by faculty?" They could choose between responses indicating that they allocated none to faculty, some, or all after ongoing obligations and reference needs were met. The responses, displayed in Table 6 , suggest that medium-sized academic libraries are following the trend set by research libraries to accept responsibility for materials selection. Twenty libraries allocate none of their funds to academic departments, 15 share funds, retaining some portion for library discretionary use, and nine stated that all discretionary funds are allocated for teaching faculty use. 
TABLE 6

FUND ALLOCATION PATTERNS

IN THREE LIBRARY TYPES

\begin{tabular}{|l|r|r|r|r|}
\hline Allocation pattern & Type 1 & Type 2 & Type 3 & Totals \\
Allocate all & 2 & 0 & 7 & 9 \\
Allocate some & 8 & 1 & 6 & 15 \\
Allocate none & 6 & 4 & 10 & 20 \\
\hline
\end{tabular}

The trend away from faculty selection is clear. The librarians in nearly half of the libraries have full responsibility for selection of materials. Many who checked this response added a comment stating that faculty participation was encouraged and that cooperation with faculty was the norm. These comments indicate that librarians share the concerns of Tuttle (36) and Danton (14) that the expertise of faculty not be disregarded. In only 20 percent of the libraries are all discretionary funds surrendered to the faculty.

Collection Development Activities

Finally, 16 activities associated with collection $-48-$ 
development were 1 isted. The list was compiled using the tasks identified by Parker and Carpenter (30), Ricking and Booth (31), and Bryant (8). After review in the testing phase, some of the terminology was changed because of confusion expressed by the testing librarians.

Respondents were asked to respond to the questions in two ways. They were to check the first column if they thought the activity was a desirable one for collection development librarians. They were to check the second column if librarians in their institution were expected to perform an activity. A large number of respondents interpreted the instructions to mean that they should check only one column for each activity. In recording the results, it was inferred that if the second column was checked, and no comment made that the activity was inappropriate, the first column would be counted as checked. When a respondent in any instance checked two columns, no inferences were made about that questionnaire. The results are displayed in Table 7. 
TABLE 7

DESIRABILITY AND EXPECTED ACCOMPLISHMENT

OF SIXTEEN COLLECTION DEVELOPMENT ACTIVITIES

\begin{tabular}{|c|c|c|c|c|c|c|}
\hline SHOULD DO & RANK & 8 & EXPECTED & RANK & 8 & ACTIVITY \\
\hline $\begin{array}{l}44 \\
40 \\
37 \\
32 \\
44 \\
32 \\
42 \\
36 \\
35 \\
19 \\
32 \\
16 \\
30 \\
32 \\
34 \\
40\end{array}$ & $\begin{array}{r}1 \\
4 \\
6 \\
10 \\
1 \\
10 \\
3 \\
7 \\
8 \\
15 \\
10 \\
16 \\
14 \\
10 \\
9 \\
4\end{array}$ & $\left|\begin{array}{r}100 \\
91 \\
84 \\
73 \\
100 \\
73 \\
95 \\
82 \\
79 \\
43 \\
73 \\
36 \\
68 \\
73 \\
77 \\
91\end{array}\right|$ & $\begin{array}{r}39 \\
31 \\
25 \\
16 \\
41 \\
25 \\
32 \\
27 \\
28 \\
16 \\
22 \\
16 \\
9 \\
6 \\
21 \\
31\end{array}$ & $\begin{array}{r}2 \\
4 \\
8 \\
12 \\
1 \\
8 \\
3 \\
7 \\
6 \\
12 \\
10 \\
12 \\
15 \\
16 \\
11 \\
4\end{array}$ & $\begin{array}{l}89 \mid \\
70 \mid \\
57 \mid \\
36 \\
93 \\
57 \\
73 \\
61 \\
64 \\
36 \\
50 \\
36 \\
20 \\
14 \\
48 \\
70\end{array}$ & 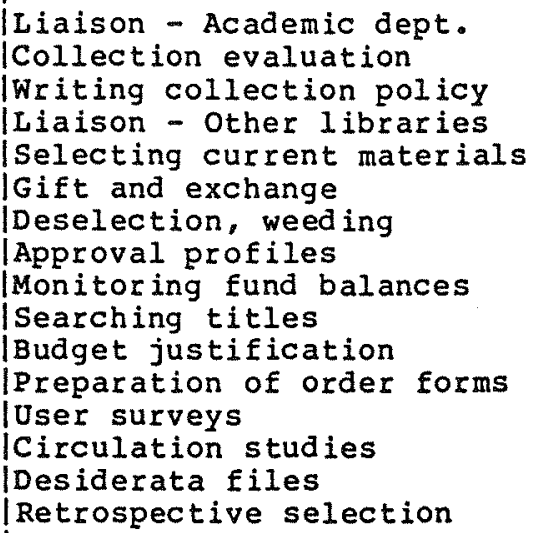 \\
\hline
\end{tabular}


The first activity listed was "Liaison with academic department." All 44 respondents checked that as a desirable activity, and 39 expected it to be done in their library. It ranked first as a desirable activity, and second as an expected activity. Those respondents who did not expect it to be done were in Type 1 or 3 libraries that allocated little or none of their funds to academic departments. They appeared to have little time to devote to collection development, and in some cases were poorly funded as well.

One respondent checked all activities as desirable, and none as expected. The comment written at the bottom of the page was, "We don't really do much more than selecting for purchase from among faculty requests."

Ranking first in both desirability and expectation was "Selecting current materials." Also near the top were "Collection maintenance: deselection, weeding," "Collection evaluation," and "Retrospective selection." These tasks were considered desirable, and it was expected that they would be done. 
Of 44 respondents, only 16 thought it appropriate for librarians to prepare orders. Many, however, apparently interpreted this as actually typing out order forms to be sent to suppliers. What was meant was preparation of request slips. Even the preparation of request slips is frequently done by clerical staff or student assistants. It may be seen as an appropriate professional activity in automated libraries where the librarians have access to the ordering system. In libraries of this type, librarians at remote terminals sometimes enter records into the system for checking, verification, and ordering by acquisitions staff.

Also low on the list of desirable tasks was "Searching titles in library catalog and/or order file." This contradicts Bryant's assertion that librarians prefer to do at least some searching because of what they learn about the collection while doing it. (8). It would be of interest to discover if librarians are more likely to choose searching the catalog and/or order file as a desirable activity in libraries with 
online catalog and/or order systems. In the author's experience, while few librarians are willing to search titles in a card catalog, many will search in an online catalog. They can do it in the privacy of an office, or during calm times at the reference desk, and they obtain circulation information about the titles they find.

Librarians also have been observed to search in an automated order system. They can find out, not only if a title is on order, but who requested it, when it was ordered, and whether it has been received. Discovering if a particular title was received on approval assists them in monitoring and maintaining the approval profile. It is unlikely, however, that a librarian would search a manual order file for anything other than one specific title, and unlikely that they would be expected to do so. While both preparation of order requests and searching titles was seen as a clerical task by 63 percent and 59 percent of respondents respectively, librarians were expected to do them when circumstances demanded in some libraries. 
Many chief collection development officers saw user studies and circulation studies as inappropriate for collection development librarians. Except for the tasks mentioned above that are often considered clerical, these were the tasks least often expected by all respondents. One respondent, however, commented that an automated circulation system had just been installed that would make such studies possible in that library.

In response to "Preparation and monitoring of approval profiles," three respondents indicated that their library did not use an approval plan. That is possibly true of others who did not mark the activity as appropriate, but who made no comment. Others indicated that monitoring fund balances was a clerical function. No doubt that depends on whether "monitoring" is interpreted as bookkeeping functions, or maintaining an awareness of how much is in a fund and whether it is being expended on schedule. Overall, an average of 12.39 activities were considered desirable, and 8.81 were expected to be 
performed. However, as shown in Table 8 , when Type 2 libraries are compared with Types 1 and 3 , it is apparent that more activities are considered desirable, and expectations are higher in these libraries.

Activities not unanimously selected as desirable in Type 2 libraries were searching titles, preparing order forms, and conducting user surveys and circulation studies. Not only did chief collection development officers in Type 2 libraries think more of the activities were desirable, (86 percent as compared to 76 percent) they expected librarians reporting to them to accomplish a higher percentage of them than did the respondents in Types 1 and 3 libraries $(65$ percent and 53 percent respectively). 
TABLE 8

DESIRABLE AND EXPECTED

COLLECTION DEVELOPMENT ACTIVITIES

COMPARISON BETWEEN LIBRARY TYPES

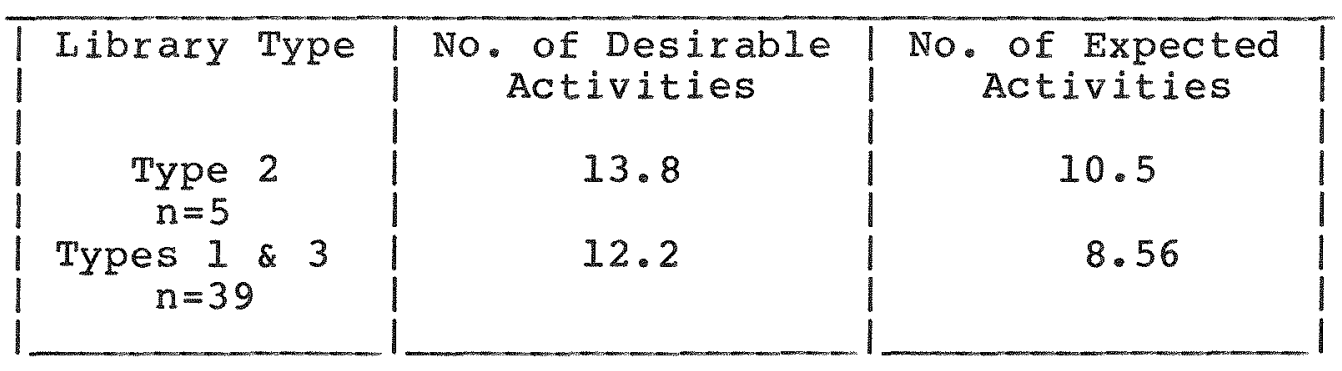

Questionnaire for Librarians with Collection

Development Responsibilities

Three hundred fifty-five of these questionnaires were sent to 71 libraries, five to each library. One hundred fifty-six were returned from 44 libraries. Nine of the questionnaires, from three libraries, were not matched by "Questionnaires for Chief Collection Development officers." These questionnaires could not be used when responses were matched to information from the Chiefs" questionnaires, but were used in other 
instances. The average return per library was 3.38 questionnaires.

\section{Librarians Assignments}

Librarians were first asked to indicate their job titles or assignments. A blank line was left for this purpose, but the responses were grouped by the investigator. A list of responses is provided in Appendix D. The grouped results are displayed in Table 9.

TABLE 9

ASSIGNMENTS OF LIBRARIANS WITH COLLECTION DEVELOPMENT RESPONSIBILITIES

\begin{tabular}{|l|r|}
\hline Assignment & Number \\
Public Services Librarian & 55 \\
Subject Specialist & 35 \\
Dept. Head in Public Services & 23 \\
Dept. Head in Tech. Services & 15 \\
Director, Assoc./Assnt. & \\
Director, Head of Branch & 13 \\
Technical Services Librarian & 10 \\
Collection Development & 4 \\
Total & 155 \\
\hline
\end{tabular}


Although the American Library Association places Collection Development in its Resources and Technical Services Division, Futas states that most collection development is done by public services librarians (20). Futas is overwhelmingly supported in this survey. Of Type 1 libraries, the department responsible for collection development was the Reference Department in ten of the 15 libraries, and the Acquisitions Department in two. In the other three, the department could not be ascertained from the questionnaires.

In responding to this question, librarians identifying themselves as subject specialists almost always included reference as part of their title also, as in Reference/Social Sciences Bibliographer. One respondent identified him/herself as the library director. Some Iibrarians identify their assignments by subject, some by function, and some by a combination of the two.

of 155 librarians responding, 35 percent $(n=55)$ identified themselves as being in some area of public service. Frequently, this was reference, or reference 
in combination with another responsibility, such as online search, instruction, or bibliographer for an unspecified subject. Another 22 percent $(n=35)$ identified themselves as subject specialists, either alone or with reference. These are identified by library type in Table 10.

TABLE 10

SUBJECT SPECIALISTS IN LIBRARY TYPES

\begin{tabular}{|l|c|c|}
\hline Library Type & Subj. Specialists & Percent \\
Type 1 & 11 & 20 \\
Type 2 & 9 & 90 \\
Type 3 & 15 & 18 \\
\hline
\end{tabular}

The only respondent in a Type 2 library not identified as a subject specialist was called a "general services librarian." In the other two types of libraries, librarians with collection development responsibilities infrequently have collection development, subject specialists, or bibliographer as part of their job titles. 


\section{Priority of Collection Development}

Respondents were asked to identify professional assignments that take priority over collection development. Ferguson and Taylor listed reference, professional development, and meetings as having priority over collection development (19). The activities listed as having priority over collection development in this survey are grouped in Table 11.

TABLE 11

ACTIVITIES LISTED AS HAVING PRIORITY

OVER COLLECTION DEVELOPMENT

\begin{tabular}{|l|r|}
\hline Activity & Listed \\
Reference desk/Public Assistance & 87 \\
Supervision and Administration & 52 \\
Bibliographic Instruction & 34 \\
None/No answer/Co-equal & 29 \\
Online Search & 23 \\
Committee work/Meetings & 16 \\
|Cataloging/Acquisitions/Serials & 12 \\
Automation & 4 \\
Preparation of Guides/Grants & 3 \\
Orientation Lan & 3 \\
Interlibrary Loan & 2 \\
\hline Archives & 1 \\
\hline
\end{tabular}

Professional development, cited as frequently 
listed in Ferguson and Taylor did not appear in this survey, but reference desk duty was 1 isted by 56 percent of respondents, and was the most frequently listed. Also frequently mentioned in this survey was supervision, administration or management (33 percent). Mentioned more than committee work and meetings (10 percent) were both bibliographic instruction (22 percent) and online search (15 percent).

One respondent listed desk duty, searching, and committee work, but then stated that

$C D$ is a serious responsibility - but one that gets "fit in" as it can. One must be on the desk at a given time, meet classes \& do searches at certain times. One can do C.D. "any time." At home one "selects" while reading the NY Times, Natural History, etc.

Another wrote "Do you mean 'are more important than?" and Iisted "reference desk, bib instruction, computerized ref searching." This was from a library that allocates all its money to faculty. Still another wrote 
In my estimation, collection development is my second priority behind service on the reference desk. Of course, reference service wouldn't exist without a good collection to draw upon. In the last few years, however, administration is placing less emphasis on collection development. Bibliographers are expected to devote more and more time to library instruction and computer searching in their areas. These newer services, for the most part, were imposed without additional staff. Hours on the reference desk have remained fairly constant. Most of the time for newer activities, therefore, is taken from collection development.

Twenty-six of the respondents left the space blank, or said that collection development was co-equal with other responsibilities, or that nothing took priority over collection development. In Table 12, the results are displayed as related to library type. Again, a greater commitment to collection development is apparent in Type 2 libraries, where a third of 
respondents said nothing takes priority over it.

TABLE 12

PRIORITY OF OTHER RESPONSIBILITIES OVER

COLLECTION DEVELOPMENT BY LIBRARY TYPE

\begin{tabular}{|l|c|c|}
\hline Library type & \% Listed others & \% Listed none \\
Type 1 & 90.7 & 9.3 \\
Type 2 & 66.6 & 33.4 \\
Type 3 & 83.1 & 16.9 \\
\hline
\end{tabular}

Librarian Qualifications for Collection Development

Respondents were asked to indicate the

qualifications they had to aid them in their collection development responsibilities. Again, a blank line was left for the response, but answers were grouped in the categories Formal Study, Experience and/or Interest, and None. The results are displayed in Table 13. 
TABLE 13

QUALIFICATIONS FOR COLLECTION DEVELOPMENT

BY LIBRARY TYPE

\begin{tabular}{|l|c|c|c|}
\hline Library Type & Study & $\begin{array}{c}\text { Experience/ } \\
\text { Interest }\end{array}$ & None/No Answer \\
Type 1 & 33 & 16 & 3 \\
Type 2 & 9 & 1 & 0 \\
Type 3 & 60 & 20 & 5 \\
Totals & 102 & 37 & 8 \\
\hline
\end{tabular}

When respondents 1 isted both formal study and interest or experience, they were placed in the study category, which represents 69 percent of respondents. Twenty-five percent cite library science courses, experience, or general education. The remaining six percent either said they were not qualified or did not have specific subject responsibilities.

An analysis separating out those listing only formal study, only interest or experience, and those listing a combination of these was done. Using these categories, 58 respondents listed only formal study, 30 listed only interest or experience, and 60 isted a 
combination of formal study and experience or interest. Five said they had no qualifications for what they were asked to do, and three responded that they had no specific subject responsibilities.

All the respondents who replied formal study only, cited course work or degrees in their subject area of responsibility. Many of the respondents in the combination category also listed subject area degrees or course work. Others, however, cited their library science education, and especially courses or seminars in collection development. One respondent gave the question a particularly broad interpretation, listing "Bibliographical skills, general interest in research, organization and communication skill."

Another stated,

I have a $\mathrm{BA}$ in my area of responsibility. However I am more knowledgeable of the subject because of my own efforts: reading \& talking to faculty, etc. In other words, my BA doesn't really help. A respondent who claimed no qualifications said, None - The subject was assigned to me by default - 
no one else was qualified on the subject \& I was new to the faculty.

A total of ninety respondents (57 percent) cited their experience, general abilities and background, or personalities as helpful in fulfilling their collection development responsibilities. One hundred eight $(69$ percent) have subject backgrounds and/or specific course work in collection development. Just three percent were unable to list any qualifications for the assignment.

Faculty Participation in Collection Development

The next question was designed to assess faculty interest and participation in collection development. Respondents were asked to indicate whether they served as a conduit for faculty book orders, worked cooperatively with faculty, or worked in areas where faculty took no interest. The results, displayed in Table 14, show a high level of cooperation. Librarians who checked the third answer sometimes wrote comments indicating their frustration with faculty lack of 
interest. As the total indicates, more than one answer was checked by many respondents.

\section{TABLE 14}

FACULTY INTEREST AND PARTICIPATION IN

COLLECTION DEVELOPMENT

\begin{tabular}{|l|r|}
\hline \multicolumn{1}{|c|}{ Interest and Participation } & Number \\
Librarian serves as conduit for orders & 81 \\
Librarian and faculty cooperate & 108 \\
Faculty take little or no interest & 36 \\
Total & 225 \\
\hline
\end{tabular}

Batz (5) found a high level of librarian selection of materials when he studied nineteen research libraries. He also found discontent among the librarians about the lack of faculty interest and lack of success in attempts to involve faculty. His results do not appear to be repeated in this study of smaller academic Iibraries.

Time Spent on Collection Development

Librarians were asked how much time they had 
assigned to collection development, and how much time they spent on it. Many responded to the first question by saying they were not "assigned" a percent of their time. The results, displayed in Table 15, show interesting differences between Type 2 libraries and other types.

TABLE 15

EXPECTED AND ACTUAL TIME SPENT

ON COLLECTION DEVELOPMENT

IN THREE LIBRARY TYPES

\begin{tabular}{|l|c|c|c|c|}
\hline Library Type & Time Assigned & \multicolumn{2}{|c|}{ Time Spent } \\
\hline & Mean & SD & Mean & SD \\
Type 1 & 25.08 & 17.77 & 24.19 & 16.26 \\
Type 2 & 51.67 & 27.84 & 42.50 & 22.64 \\
Type 3 & 23.80 & 19.93 & 22.79 & 18.60 \\
\hline
\end{tabular}

Sloan (32) found that collection development librarians in Type 2 organizations spent more of their time on collection development than did librarians in Type $I$ and Type 3 libraries. Sloan's findings were repeated in this study. Although librarians in Types 1 and 3 organizations come closer to spending the time 
assigned to collection development, that time, as was shown in Table 2, frequently was quite a low percentage of total time. Librarians in Type 2 organizations miss achieving their assignments by nearly 10 percentage points, but still spend nearly twice as much time on collection development as do their colleagues in Types 1 and 3.

TABLE 16

SIX STATEMENTS

\begin{tabular}{|c|c|c|c|c|}
\hline Statement & $\begin{array}{l}\text { Strongly } \\
\text { Agree }\end{array}$ & Agree & Disagree & $\begin{array}{l}\text { |Strongly| } \\
\text { |Disagree| }\end{array}$ \\
\hline $\begin{array}{l}\text { I have time to fulfill my collection } \\
\text { development responsibilities }\end{array}$ & 9 & 64 & 45 & 13 \\
\hline $\begin{array}{l}\text { I defer collection development } \\
\text { responsibilities to other }\end{array}$ & & & 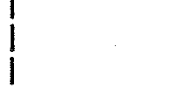 & 1 \\
\hline professional activities & 14 & 54 & 57 & 12 \\
\hline $\begin{array}{l}\text { Faculty respect my professional } \\
\text { qualifications and have confidence }\end{array}$ & & & & 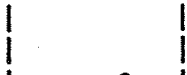 \\
\hline in my ability to select materials & 28 & 95 & 9 & 0 \\
\hline $\begin{array}{l}\text { Faculty have confidence in my } \\
\text { ability to weed materials from }\end{array}$ & & & & \\
\hline the collection & 17 & 76 & 19 & 3 \\
\hline $\begin{array}{l}\text { I need more formal study in order } \\
\text { to do a satisfactory job of }\end{array}$ & & & & \\
\hline collection development & 2 & 29 & 77 & 32 \\
\hline $\begin{array}{l}\text { The organizational structure of my } \\
\text { library supports and rewards } \\
\text { collection development activities }\end{array}$ & 11 & 68 & 41 & 16 \\
\hline
\end{tabular}


Six Statements

Librarians were asked to respond to six statements using a scale ranging from strongly Agree to strongly Disagree. The results are displayed in Table 16. More than half of the respondents said they had sufficient time to fulfill their collection development responsibilities. Half said they deferred collection development to other responsibilities. Fifty eight percent stated that their library's organizational structure supported and rewarded collection development.

Stronger opinions emerged when librarians were asked about their need for more education, and about faculty perceptions of their qualifications. In response to the statement "Faculty respect my professional qualifications and have confidence in my ability to select materials," only seven percent disagreed, and none strongly disagreed. Respondents were slightly more cautious about weeding, with 19 percent disagreeing with the statement that faculty had confidence in their ability to perform that chore. 
Just 22 percent of respondents felt they needed more formal study in order to do a satisfactory job of collection development.

In a survey examining faculty perceptions of librarians at the University of Manitoba, the investigators found that faculty generally viewed librarians as "professionals" performing a "service" function, rather than as colleagues (17). However, they regarded subject expertise and advanced degrees in subject areas to be most important for fulfilling collection development responsibilities. This was true to a greater extent in the humanities, social sciences, and education, than in the sciences.

In order to ascertain if respondents to this study perceived a relationship between faculty respect for qualifications and advanced subject master's degrees, a contingency table was constructed using the responses to statement 9 and the qualifications listed in Question 3. For this analysis, only a master's degree was counted, not master's level study or bachelor's degrees. The results, displayed in Table 17, show that 
the participants in this study perceive no relationship between an advanced subject degree and faculty regard. Ninety percent of librarians not stating a subject master's as a qualification felt that faculty respected their qualifications and their ability to select materials.

\section{TABLE 17}

RELATIONSHIP BETWEEN ADVANCED SUBJECT EDUCATION AND PERCEPTIONS OF FACULTY RESPECT FOR QUALIFICATIONS

\begin{tabular}{|l|c|c|}
\hline Education & Have Respect & Don't Have Respect \\
ISubj.Master & 53 & 1 \\
INo 2d Master & 75 & 8 \\
\hline
\end{tabular}

Some librarians wrote comments on this section of the questionnaire. Next to the statement about weeding, comments included:

"Question is about to be dealt with shortly." "They trust only themselves, but I do it anyway." "Faculty get very upset when they hear anything is being discarded."

"We don"t discard the last copy without consulting 
with faculty."

Some respondents were unable to generalize about this statement, saying it depended on individuals. Forty-one marked it as "N/A" or left it blank, indicating that no weeding was done.

Collection Development Activities

Librarians with collection development responsibilities were asked to respond to the same list of activities that chief collection development officers responded to. They were asked to check the activities they thought they should do, and the ones they had actually done at some time in the previous twelve month period. It was expected that librarians would check both columns when they did activities they thought were appropriate. However, many seemed to feel that they could check only one column or the other. In these cases, it was inferred that if they did an activity, they felt that it was one they should be doing. The results are displayed in Table 18. 
TABLE 18

SIXTEEN COLLECTION DEVELOPMENT ACTIVITIES

RATED AS DESIRABLE AND ACCOMPLISHED BY

COLLECTION DEVELOPMENT LIBRARIANS

\begin{tabular}{|c|c|c|c|c|c|c|}
\hline SHOULD DO & RANK & 8 & DID & RANK & 8 & ACTIVITY \\
\hline 149 & 2 & 951 & 143 & 2 & 921 & ILiaison - Academic dept. \\
\hline 146 & 3 & 941 & 87 & 9 & 56 & Collection evaluation \\
\hline 118 & 7 & 761 & 46 & 13 & 29 & Writing collection policy \\
\hline 93 & 13 & 601 & 45 & 14 & 29 & ILiaison - Other libraries \\
\hline 154 & 1 & 991 & 152 & I & 97 & Selecting current materials \\
\hline 104 & $\overline{9}$ & 671 & 92 & $\overline{7}$ & 59 & Gift and exchange \\
\hline 139 & 4 & 89 & 88 & 8 & 56 & Deselection, weeding \\
\hline 103 & 11 & 661 & 71 & 11 & 45 & Approval profiles \\
\hline 119. & 6 & 761 & 112 & 3 & 72 & Monitoring fund balances \\
\hline 104 & 9 & 671 & 110 & 4 & 70 & Searching titles \\
\hline 85 & 16 & 541 & 58 & 12 & 37 & Budget justification \\
\hline 92 & 14 & 59 & 98 & 5 & 63 & Preparation of order forms \\
\hline 87 & 15 & 56 & 17 & 16 & 11 & Uuser surveys \\
\hline 105 & 8 & $67 \mid$ & 30 & 15 & 19 & Circulation studies \\
\hline 99 & 12 & 631 & 73 & 10 & 47 & Desiderata files \\
\hline 129 & 5 & $83 !$ & 97 & 6 & 62 & Retrospective selection \\
\hline
\end{tabular}


Not surprisingly, librarians were not able to do all the things they felt they should do. The two activities ranked first and second as important to do, also ranked first and second as activities done. These were selecting current materials and acting as liaison to an academic department. Almost as many librarians said they did them as said they should do them. After that, however, discrepancies arise.

Collection evaluation is ranked third as an activity that should be done, but ninth as an activity that was done. Only 59 percent of those saying it should be done had found time to do it. Also notable is Weeding, with 139 librarians saying it should be done, but only 88 finding time to do it. Similarly, 118 felt that writing collection development policy is desirable, but only 46 , or 38 percent, had done it. Although circulation studies were ranked eighth, with 105 respondents thinking them desirable, they ranked fifteenth in activities done.

When the results are compared with the responses to the same list from Questionnaire \#1, the same tasks 
are ranked in the top five by both groups. However, the task ranked fifteenth by chief collection development officers, searching titles in the catalog, was given more importance by collection development librarians. They ranked it ninth, over gift and exchange work, approval profiles, maintenance of desiderata files, and liaison with other libraries. Collection development librarians also accorded more importance to circulation studies than did their supervisors, but neither group ranked user studies as useful. That item was selected by just 68 percent of chief collection development officers and 56 percent of collection development librarians.

Responses from Type 2 libraries were analyzed separately. The results showed that all ten respondents considered Liaison with Departments, Selecting Current Materials, Gift and Exchange work, Monitoring Fund Balances, Searching Titles, Budget Justification, and Preparation of order Forms to be suitable activities, and activities that all had done. Also chosen as desirable by all ten were collection 
Evaluation and Collection Maintenance (Weeding), but only nine had done each. The histograms in Charts 1 and 2 demonstrate the differences between the responses from Type 2 Libraxies and the responses from all libraries.

At first glance, it appears that in Type 2 libraries, seven tasks are performed by all of the librarians who say they are desirable, and that the same is true of three of the tasks when responses from all library types are considered. However, it should be noted that tasks ten and twelve create a misleading impression. These tasks, searching titles in the catalog or order file, and preparation of order forms, were frequently marked as tasks done by librarians even though they were considered to be clerical.

Disregarding these two tasks, then, it can be seen that in Type 2 libraries, all the librarians who said they should act as liaisons to academic departments, select current materials, participate in $\mathrm{g}$ ift and exchange, weed, monitor fund balances, and do budget justifications, were able to do those things. In all 
libraries, however, only selection of current materials was achieved by nearly 100 percent of those who had it as a goal.

Collection evaluation, ranked desirable by 94 percent of collection development librarians and 91 percent of chief collection development officers, was a goal attained by 90 percent of those striving for it in Type 2 libraries, but by 60 percent in all libraries. Writing collection development policy did not fare so well in any type of library, with an achievement rate of 40 percent in all libraries, and just 50 percent in Type 2 libraries.

Circulation studies and user surveys were the tasks least likely to be done, even by librarians who think they are useful. The achievement rate for all libraries is 20 percent for user surveys and 30 percent for circulation studies. In Type 2 libraries they are 50 percent and 40 percent respectively. 


\section{CHART 1}

PERCENTAGE OF DESIRABLE ACTIVITIES ACCOMPLISHED

IN ALL LIBRARIES RESPONDING

Tasks

$\begin{array}{lllllllllllllllll}1 & 2 & 3 & 4 & 5 & 6 & 7 & 8 & 9 & 10 & 11 & 12 & 13 & 14 & 15 & 16\end{array}$

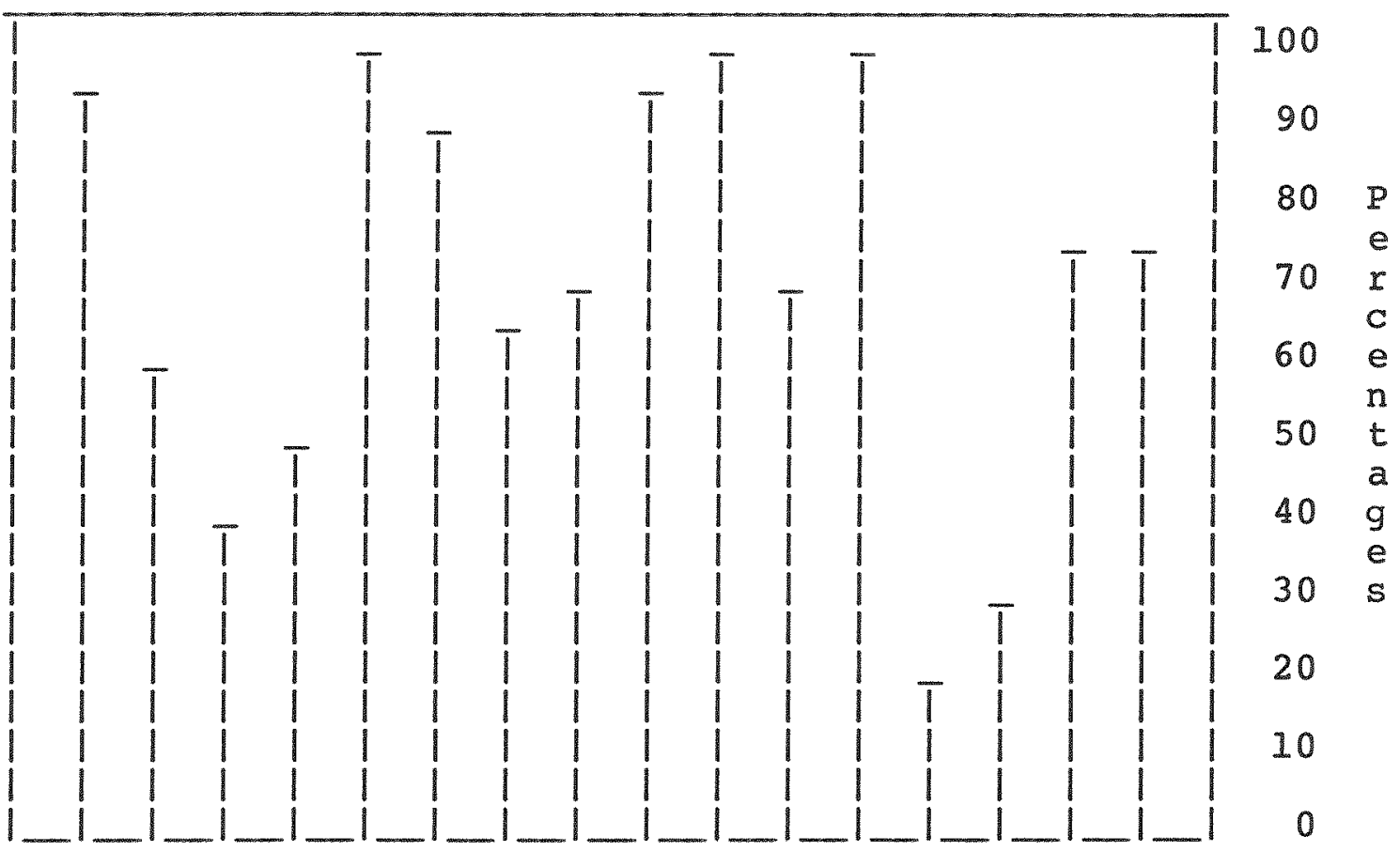

1. Liaison, department

2. Collection evaluation

9. Fund allocation

3. Writing policy

4. Liaison, outside

5. Selecting materials

6. Gift and exchange

7. Weeding

8. Approval profiles

10. Searching titles

11. Budget allocations

12. Preparing orders

13. User studies

14. Circulation studies

15. Desiderate files

16. Retrospective selection 
CHART 2

PERCENTAGE OF DESIRABLE ACTIVITIES ACCOMPLISHED

IN TYPE 2 LIBRARIES

Tasks

$\begin{array}{llllllllllllllll}1 & 2 & 3 & 4 & 5 & 6 & 7 & 8 & 9 & 10 & 11 & 12 & 13 & 14 & 15 & 16\end{array}$

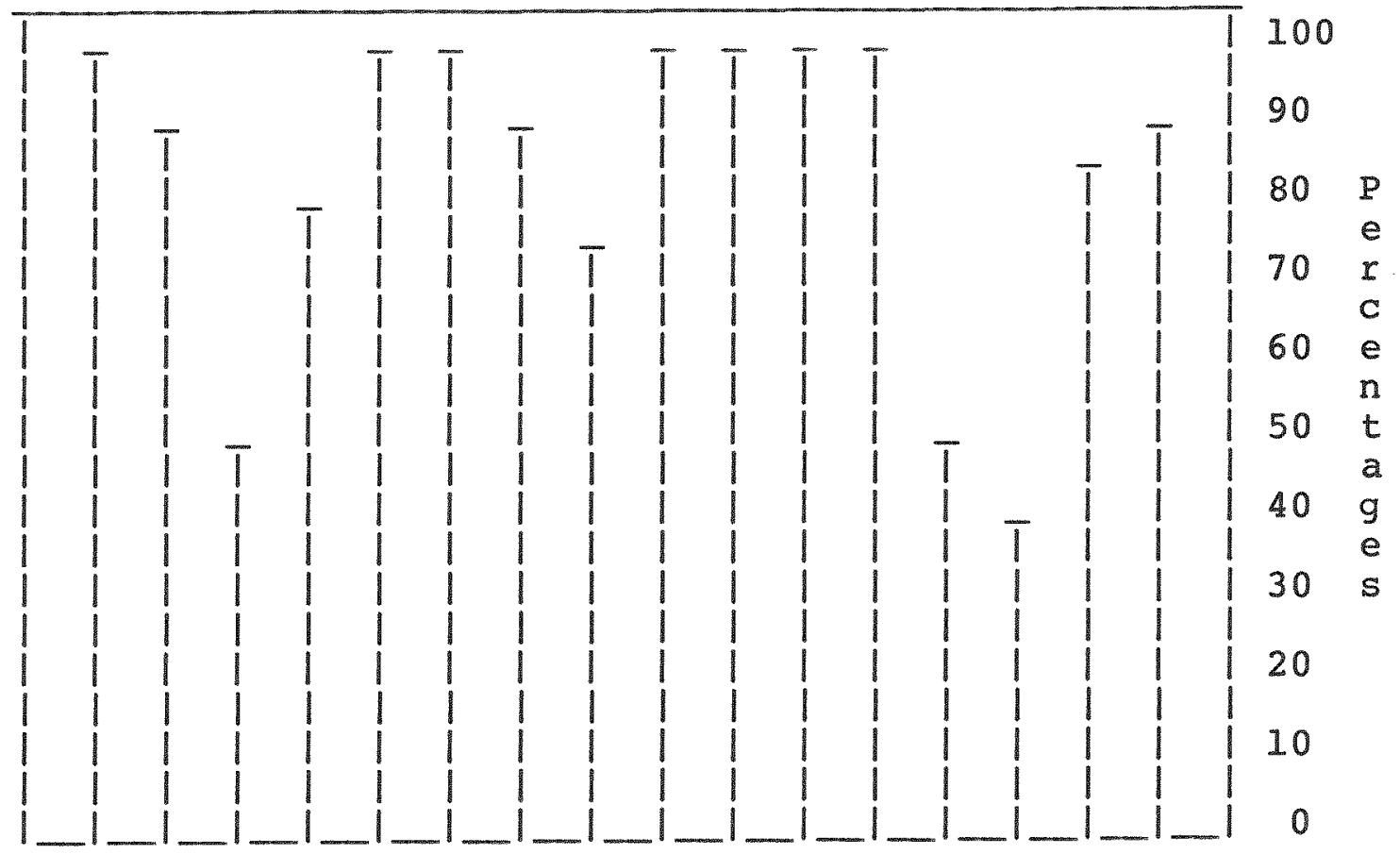

1. Iiaison, department

2. Collection evaluation

9. Fund allocation

3. Writing policy

4. Liaison, outside

5. Selecting materials

6. Gift and exchange

7. Weeding

8. Approval profiles

10. Searching titles

11. Budget allocations

12. Preparing order

13. User studies

14. Circulation studies

15. Desiderate files

16. Retrospective selection 
CHAPTER EIVE

Summary and Conclusions

Answers to Research Questions

At the beginning of the study, twelve research questions were posed. While detailed answers to these questions are to be found in Chapters Four and Five, brief answers are provided here.

1. Is there a prevalent organizational model in medium-sized academic libraries? Medium-sized academic libraries are most likely to be organized for collection development in a Type 1 or Type 3 model, with Type 1 slightly more prevalent.

2. Does the organizational model affect the way collection development is done? Yes, collection development is more likely to be neglected in a Type 1 or Type 3 organizational model. Moreover, a larger percentage of total professional time will be assigned to collection development in a Type 2 library.

3. Do libraries of this size typically allocate funds $-81-$ 
for faculty expenditure, or retain control of them? Twenty libraries allocated none of their funds for faculty expenditure, fifteen allocated some, and just nine allocated all.

4. Are librarians with collection development responsibilities typically administratively assigned in public services or technical services? The typical assignment is in public services.

5. What relationship is there between administrative assignment of librarians and the amount of time spent on collection development? Librarians in public services departments have more demands on their time, with the effect that their time for collection development is eroded.

6. What relationship is there between administrative assignment of librarians and the collection development activities they perform? Librarians with administrative assignments in public services departments are more likely to concentrate on liaison work with faculty and selection of materials. Librarians with administrative 
assignments in technical services or a collection development department do those things, but also are more likely to write collection development policies, evaluate collections, and do circulation and user studies.

7. Do librarians defer collection development to other duties.? Yes, especially librarians in Type 1 and Type 3 libraries, and librarians with administrative assignments in public services.

8. How are librarians academically or experientially prepared to do collection development? Many have master"s degrees or course work in the subjects they are responsible for. Others cite interest and experience.

9. Do librarians feel adequately prepared educationally for their collection development responsibilities? Almost all librarians responding felt adequately prepared for their assignments.

10. Do librarians feel that faculty respect their qualifications and judgment? Librarians indicated 
a high degree of faculty respect.

11. What tasks do librarians feel are appropriate or necessary for collection development? Of sixteen tasks listed, the five most frequently selected as desirable were: liaison with academic department: selecting current materials; deselection, weeding: retrospective selection, and evaluation of collections.

12. How many of these tasks do they perform? of the top five tasks selected, 97 percent of responding collection development librarians, or librarians with collection development responsibilities selected current materials; 92 percent functioned as liaisons with academic departments. Weeding and collection evaluation were accomplished by 56 percent of respondents, and 62 percent said they did retrospective selection.

\section{General Summary}

The purpose of this study was to determine if there is a way of organizing for collection development 
in medium-sized academic libraries that can be advocated as most effective. Sloan (32) and Howard (24) do not advocate any organizational type over another. The results of this study show, however, that when librarians are appointed to do collection development in a library that has identified it as a separate activity worthy of its own department, more time is devoted to it, and more activities associated with collection development are accomplished. The study also showed that librarians in these libraries, identified as Type 2 organizations, did a higher percentage of the activities they thought desirable than did their colleagues in Type 1 and 3 libraries. When activities achieved were calculated as a percentage of activities desired, the achievement rate of librarians in Type 2 libraries was a mean of 80 percent and in all libraries, just 66 percent.

The research hypothesis was supported. The organizational structure of the medium-sized academic library affects collection development activities. In most of the libraries surveyed, it affected them 
negatively. Because most librarians with collection development responsibilities in academic libraries of the size surveyed are not in permanent collection development departments, their time for collection development is eroded by other responsibilities and demands on their time. When time is not available for everything that needs to be done, collection development frequently is the task that is neglected. This conclusion is supported by statements volunteered by respondents as well as by the evidence supplied in Charts 1 and 2 , and in Table 12 .

What the study did not show was the results of the greater time spent and activities accomplished. Are the collections in those Type 2 libraries meeting the needs of their users better than the collections in the other libraries? One way of finding the answer to that question is through user surveys, circulation studies, and collection evaluation, activities more likely to be done in Type 2 libraries than in Types 1 and 3 . In fact, it is the activities not likely to be done that define the difference between real collection 
development and simply buying materials.

The Collection Development Policy

An example is writing collection development policies. Atkinson details how the collection development policy evaluates the collection as it is, describes the means to generate a collection that is desired, and makes clear to the selectors and their constituencies that there is a well-thought-out plan for making use of materials funds (4). Librarians or faculty selecting materials for a collection that has no written collection development policy may be working at cross purposes or to no purpose. The collection is likely to have no coherence apparent to its users, and no relation to their needs or the goals of the organization.

Parker stated, however, that the actual selection of titles receives a higher priority than writing collection development policy statements even though policies are the foundation of good selection. In other words, the 
money must be spent or returned to the state, but writing policy statements can be delayed. Because many collection development activities are not as visible as public service activities and because they do not have to be conducted at rigidly scheduled times, it is easy to delay them or neglect them entirely $(30, p .479)$.

This statement is strongly supported by the results of this survey. Collection policy writing is not ranked particularly high as a desirable activity, and even lower as an accomplished one.

\section{Circulation studies}

Since librarians in Types 1 and 3 libraries said they were most likely to select materials and liaison with academic departments, and since they said that there was a high level of faculty participation in collection development, the inference is that both librarians and faculty are selecting materials based on intuitive and anecdotal evidence rather than documented need or according to plan. Librarians in Type 2 
libraries are more likely to be selecting materials based on evaluations of the collection, written plans, and the results of circulation and user studies. Many librarians in Types 1 and 3 libraries do not believe that these activities are necessary. They may agree with Futas (20), that librarians in public services know from dealing with the public what they want, what is in other libraries, and what should be purchased. This attitude dismisses the potential user who has given up on the library because it did not meet his or her needs. It also ignores the user who bypasses public service desks, going directly to the collection. Because of these factors, although user studies and circulation studies sometimes affirm what librarians had suspected, at other times they reveal surprising results.

In a library supporting a university with technical emphasis, any of the librarians would have said with confidence that the computer science books were heavily used. The non-professional staff working in shelving would have agreed. A preliminary 
circulation study confirmed this commonly held view. Using Lancaster's stress formula, in which percentage of the collection is compared to percentage of circulation (25), a stress factor of 2.41 was found in the QA classification, which includes computer science books.

Further analysis was done, however, that was much more revealing. An analysis of a ten percent sample of all circulating titles in the QA classification showed that computer science books were extremely heavily used, thus confirming the intuitive wisdom of the staff. What was found that had not been predicted was that books on fluid mechanics and on the teaching of high school algebra also were in the QA classification, and also were extremely heavily used (12). The reference librarians were unaware of that use, because they were receiving no questions in those areas at the reference desk.

Knowledge of the sort gained in a circulation study such as the one described above is invaluable in making selection decisions. The librarian with 
collection development responsibilities for the sciences in that library knows of the need to buy books in all three subject areas mentioned, not just in computer science. Moreover, the study helped determine what sorts of books are needed in computer science. It was possible to make deductions about curriculum-related use, and use that was related to independent study. A user study would do even more to refine that information, which then would to be related to a collection development policy before purchasing decisions were made.

\section{User Studies}

An example of the $k$ ind of information that can be gained from a user study is detailed in a paper by Cubberley and Centini (11). The same kind of circulation study as the one reported above had indicated stress in the RT classification, where books on nursing are classified. A survey of the nursing students showed that they were more dissatisfied with library services than was a control group, that they 
were going to other libraries rather than relying on their university library, and that they were particularly unhappy with the journal collection. The journal collection, of course, is not included in circulation statistics, but the circulation statistics alerted the investigators to a user group to survey, and the survey gave them more information than the circulation study could.

Use of Available Time

Since librarians indicated that they felt adequately prepared both educationally and experientially to do collection development, but indicated that they did not have enough time to devote to it, and that they deferred it to other professional activities, it seemed important to determine what they would do if they had more time. The analysis of the responses to the sixteen activities revealed that they would devote more time to collection evaluation, writing collection development policies, weeding, and doing circulation and user studies. The analysis of 
the responses of the librarians in Type 2 libraries revealed that those respondents do devote more time to those activities.

Recommendations for Implementation

On the basis of those responses, it is safe to recommend that library administrators who are serious about collection development, who want to retain control of and responsibility for their materials funds, and who have confidence in the professional qualifications of their staffs, consider establishing a separate department for collection development. If reorganization of the present staff is not feasible, reorganization can take place incrementally as staff positions become vacant. Collection development can gradually be transformed from a responsibility that is spread among many librarians with primary responsibilities in public services, to a responsibility that is centered in a department in technical services, and that has fewer librarians assigned to it, but who have collection development as 
their primary responsibility.

These librarians should be recruited for their subject backgrounds or experience, and if they do not have experience in collection development, they should receive structured, formal training from the chief collection development officer in the library. This training should begin with discussion of and agreement on collection development philosophy, so that the librarians are working toward common goals. In discussions including all collection development librarians and the chief collection development officer, the tasks expected of the librarians should be established, priorities established, and plans made for their implementation.

Workshops in collection evaluation, circulation studies, user studies, and writing collection development policies should be conducted if these activities are included in the responsibilities of the librarians. It could be especially useful to pair novices with librarians experienced in collection development techniques, or for the chief collection 
development officer to spend extra time working with newcomers to the specialty.

In order to counter any charges of elitism, and to prevent jealousy, the collection development librarians should contribute to other activities in the library. Such activities also would serve to keep them in touch with their colleagues, the library's public, and the demands placed on the collection on a daily basis. Some possibilities are serving at the reference desk, providing bibliographic instruction in their subject areas, or cataloging. Office space and support staff in technical services should be provided.

Such an arrangement should be tested by conducting user surveys among both faculty and students on a regular basis. If organization of the type described enhances collection development, such results should be reflected in the perceptions of the library's clientele. In addition, further study of preparation of librarians for collection development would be in order, as well as faculty perceptions of librarians. 
Further Research Needs

The present study offers exciting prospects for further research. It is apparent that the librarians in this study and the faculty members surveyed by Divay (17), have widely divergent views on the need for advanced study on the part of librarians doing collection development. It would be useful to learn if there is a difference in the usefulness of collections developed by librarians with advanced degrees in their areas of responsibility, and those without.

It would be useful, as well, to learn if the differences discovered in this study between Type 2 libraries and other types, result in measurable differences in their collections. One possibility is comparative collection evaluations, circulation studies, and user studies between libraries reporting high levels of collection development activities and libraries reporting low levels. Such studies should begin to indicate if there are discernible differences between the effectiveness and usefulness of collections developed using the techniques commonly accepted in the 
profession and collections developed using intuitive methods.

Another possibility exists in the prospect of case study analyses. Librarians who are spending substantial amounts of time on collection development, and who indicated in this study that they have time to accomplish many of the tasks identified in the survey, might keep diaries of their collection development activity. Such diaries could be the basis of the kind of analysis called for by Bryant, that describe the amount of time needed for collection development in various disciplines (8).

As one of the respondents pointed out, reference work depends on good collection development work having been done to support it. Online search can put researchers in touch with a world of information beyond the physical walls of the library. Bibliographic instruction can make students aware of the possibilities presented by the library, and some of the beginning techniques for tapping the resources. But only collection development can ensure that the bulk of 
the materials needed by the majority of the people entering the library will be immediately available when they want it. 


\section{REFERENCES}

1. The ALA Glossary of Library and Information Science. Chicago: American Library Association, 1983.

2. American Library Association. ALA Handbook of Organization 1986/1987. Chicago: The Association, 1986.

3. American Library Directory. 39th edition edited by Jaques Cattell Press. New York: Bowker, 1986.

4. Atkinson, Ross. "The Language of the Levels: Reflections on the Communication of Collection Development Policy." College \& Research Libraries 47 (March 1986): 140-49.

5. Baatz, Wilmer H. "Collection Development in 19 Libraries of the Association of Research Libraries." Library Acquisitions: Practice and Theory 2 (1978) 98-100.

6. Bonn, George S. "Evaluation of the Collection." Library Trends 22 (January 1974) 264-304.

7. Broadus, Robert N. Selecting Materials for Libraries. New York: H. W. Wilson, 1973. 
8. Bryant, Bonita. "Allocation of Human Resources for Collection Development." Library Resources and Technical Services 30 (April/June 1986) 149-162.

9.

"Collection Development Policies in

Medium-Sized Academic Libraries" Collection Building 2 (1980) 6-26.

10.

"The Organizational Structure of Collection

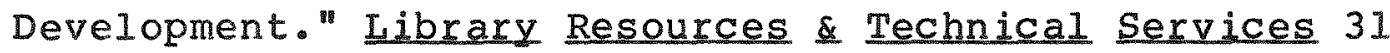
(April/June 1987) 111-122.

11. Cubberley, Carol W. and Barry Centini. "Improving Library Services for Nursing Students in an Academic Library" Collection Management 10 (November 1987).

12. _- and Jeannette Ward. Report of a Study of

Stress in the QA Section at the Library of the University of Central Florida, 1985.

13. Curley, Arthur and Dorothy Broderick. Building Library Collections. 6th ed. Metuchen, N. J.: Scarecrow, 1985.

14. Danton, J. Periam. "The Subject Specialist in National and University Libraries, with Special Reference to Book Selection." Libri 17 (1967) 42-58. 
15. DeVilbiss, M. I. "Approval Built Collection in the Medium-Sized Academic Library." College and Research Libraries 36 (November 1975) 487-492.

16. Dickinson, Dennis W. "Subject Specialists in Academic Libraries: The Once and Future Dinosaurs." New Horizons for Academic Libraries: Papers Presented at the First National Conference of the Association of College and Research Libraries, Boston, Mass., November 8-11. 1978 Ed. Robert D. Stueart and Richard D. Johnson. New York: Saur, 1979.

17. Divay, Gaby, Ada M. Ducas, and Nicole Michaud-Oystryk. "Faculty Perceptions of Iibrarians at the University of Manitoba." College \& Research Libraries 48 (January 1987) 27-35.

18. Duino, A. R. "Role of the subject specialist in British and American University Libraries: A Comparative Study." Libri 29 (March 1979) 1-19.

19. Ferguson, Anthony $W$. and John R. Taylor. "What Are You Doing?' An Analysis of Activities of Public Service Librarians at a Medium-Sized Research Library." Journal of Academic Librarianship 6 (March 1980) 24-29. 
20. Futas, Elizabeth."The Role of Public Services in Collection Development." Library Trends 33 (Winter 1985) $397-415$.

21. Gardner, Richard K. Library Collections: Their Origins, Selection, and Development. New York: McGraw-Hill, 1981.

22. Haro, Robert. "The Bibliographer in the Academic Library." Library Resources and Technical Services 13 (Spring 1969) 163-69.

23. "Book Selection in Academic Libraries." College and Research Libraries 28 (March 1967) 104-106. 24. Howard, Helen A., "Organization Theory and its Application to Research in Librarianship." Library Trends 32 (Spring 1984) 477-493.

25. Lancaster, F. W. "Evaluating Collections By Their Use." Collection Management 4 (Spring/Summer 1982): 15-43.

26. Magrill, Rose Mary and Doralyn J. Hickey. Acquisition Management and Collection Development in Libraries. Chicago: American Library Association, 1984. 
27. Messick, Frederic M. "Subject Specialists in Smaller Academic Libraries." Library Resources and Technical Services 21 (Fall 1977) 368-74.

28. Osburn, Charles B. "Collection Development: The Link Between Scholarship and Library Resources." In New Directions for Higher Education: Priorities for Academic Libraries, no. 39. San Francisco: Jossey-Bass, 1982 .

29. "Toward a Reconceptualization of Collection Development," In Advances in Library Administration and Organization V.2. Greenwich, Connecticut: JAI Press, 1983.

30. Parker, Diane C. and Eric J. Carpenter. "A Zero-Base Budget Approach to Staff Justification for a Combined Reference and Collection Development Department." In New Horizons for Academic Libraries: Papers Presented at the First National Conference of the Association of College and Research Libraries, Boston. Mass. November 8-11. 1978. Ed. Robert D. Stueart and Richard D. Johnson. New York: Saur, 1979. 
31. Ricking, M. and Robert E. Booth. Personnel Utilization in Libraries: A Systems Approach. Chicago: American Library Association, 1974.

32. Sloan, Elaine F. "The Organization of Collection Development in Large University Research Libraries." Ph.D. dissertation, University of Maryland, 1973.

33. Smith, Eldred. "The Impact of the Subject Specialist Librarian on the organization and structure of the Academic Research Library." In The Academic Library. Ed. Evan Ira Farber and Ruth Wallig. Metuchen, N. J.: Scarecrow, 1974.

34. Sohn, Jeanne. "Collection Development Organizational Patterns in ARL Libraries." Library Resources \& Technical Services 31 (April/June 1987) 123-134.

35. Stueart, Robert D. "The Area Specialist Bibliographer: An Inquiry Into His Role." Metuchen, N. J.: Scarecrow, 1972.

36. Tuttle, Helen Welch. "An Acquisitionist Looks at Mr. Haro's Bibliographer." Library Resources and Technical Services 13 (Spring 1969) 174-177. 
37. United Faculty of Florida Library Survey. University of Central Florida, Orlando, 1986.

38. Woodhead, Peter and J. V. Martin. "Subject

Specialization in British University Libraries : A Survey." Journal of Librarianship 14 (April 1982) 93-108. 


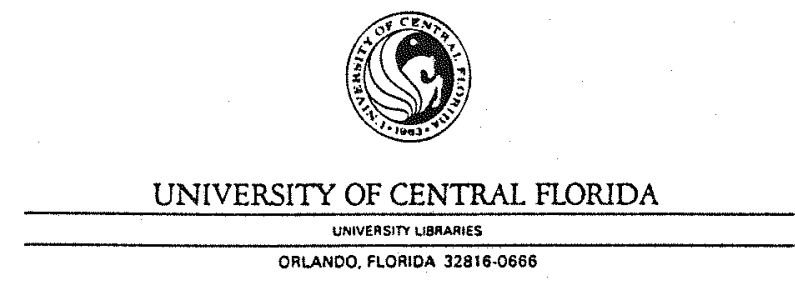

Deceaber 30,1986

Deax Colleague:

As coordinator of Collection Development in the Library at the University of Central Florida, of Central Florlda, thave become interested in the allocation of human resources for chls assignment in other acadeaic librarles. I also ar Interested in the various activities associated with collection developmen and whether there is signif.

As one of the requitements for the degree Doctor of Arts in Information Science frow Nova Universiey, I an conduefing a survey of academic librartes in an effort to find answers to thege questions. The survey fnstruments are based on an extensive literature review, which reveals that my concerns are widespread in the profession. I would be most grateful if you and your colleagues assist me in this study.

Enclosed are stx questionnatres. One is to be completed by the chief collection developwent offlcer in your librazy. The other five are to be coapleted by bibllographers, subject speclailgcs, or other librartans with collection development responsibilitfes. Five coples are provided so that many, If not all, such 11brarians can particlpate. Completion of the questionna1res takes ten axinutes at most. I have included postagempald envelopes for their return.

For questionnafres to be included in the results, they should be postmarked no Later than January 31,1987 . Complete confident1ality w111 be malntained. and particlpating libraries will be provided uth a copy of the results.

Yours sincerely.

Carol Cubberley

Head, Acquisfitions and Collection Development 
1. Which model most nearly describes your library's organization for collection development?

Type I. Collection development is not a separate activity. It is one of the responsibilities of a department established for another purpose, such as reference or acquisitions.

Type II. Collection development is regarded as a separate activity. There is a department established for this purpose with librarians assigned there either full time or as a principal job assignment.

Type III. Collection development is regarded as a separate activity. There is an assistant director, coordinator, or department head responsible for it. Librarians with collection development assignments are members of other departments and have their primary responsibilities in those other departments.

2. Librarians with collection development responsibilities typically are expected to spend what percentage of their time on collection development?
$0-10 \%$
$26-50 \%$
$76-100 \%$

$11-25 \%$

$51-75 \%$

3. Librarians with collection development responsibilities actualiy spend what percentage of their time on collection development?

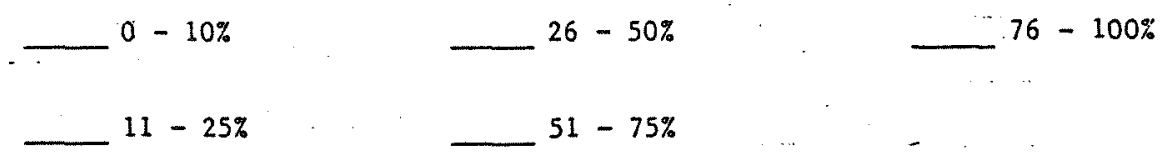

4. What is the full time equivalent of professional librarians in your 1ibrary?

5. What is the full time equivalent of librarian time assigned to collection development activities? (Corresponds to Question \#2 above.) 
6. Does your library allocate money to academic departments for expenditure by Eaculty?

Yes, all after recurring expenses, reference, replacements, and so forth are provided for.

Some, but some also reserved for librarian expendicure.

None.

7. Listed below are sixteen collection development activities. Please check the ones you think librarians should do, and the ones librarians in your library are expected to do.

Should do Expected

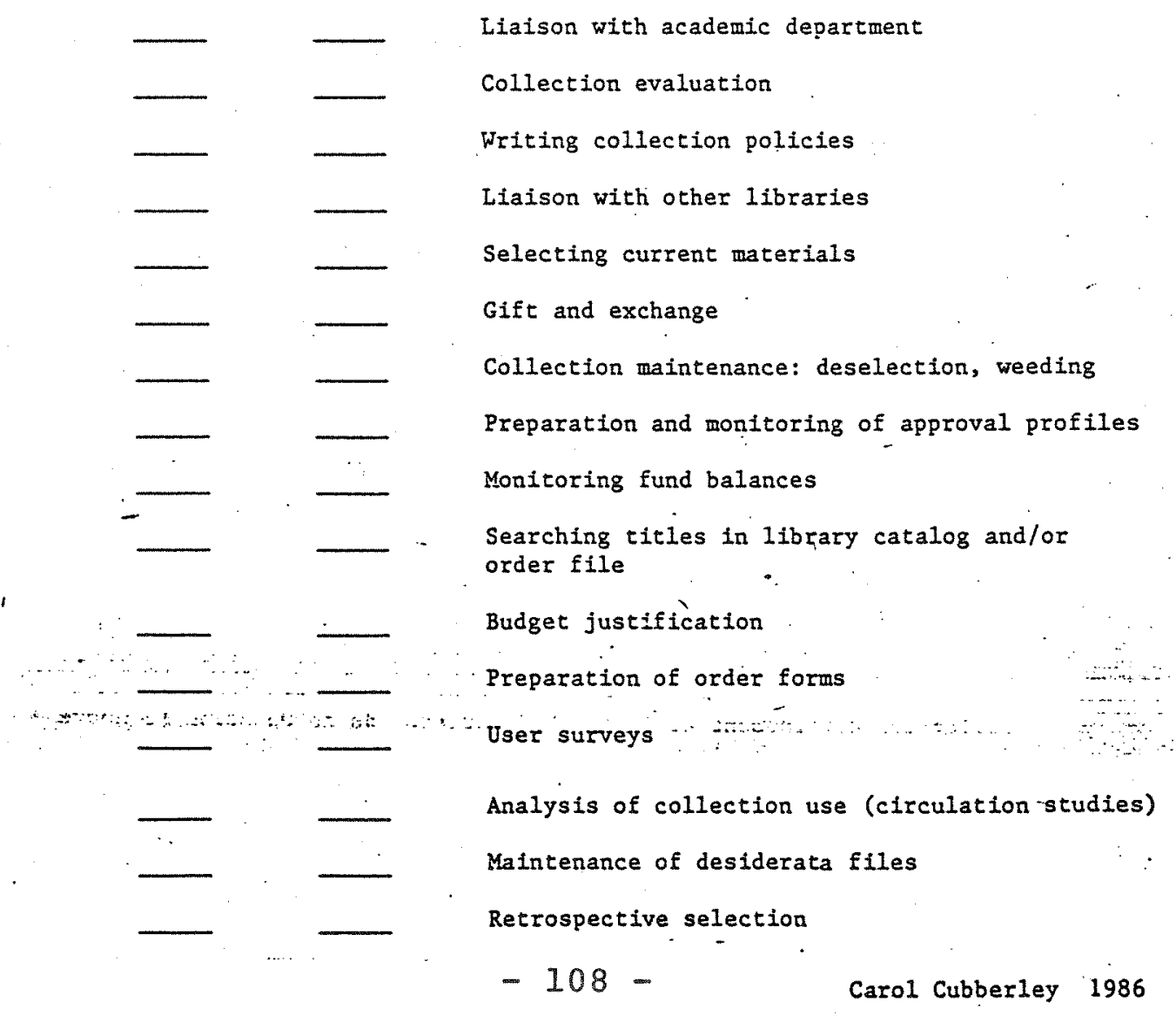




\section{APPENDIX C}

Questionnaire

For Librarians with Collection Development Responsibilities

1. What is your job title or assignment? (Not rank, but Reference tibrarian, or Head of Circulation, for instance.)

2. What professional assignments do you have that take priority over collection development?

3.' What qualifications do you have that you feel aid you in the subject area[s] of your responsibility?

4. Which statement most nearly describes your relationship with faculty in the subject area[s] of your responsibility? (Check more than one if necessary.)

I serve as a conduit for faculty book orders.

I work closely with faculty, anticipate their needs, and frequently have already ordered the books they request.

Faculty take little or no interest in collection development.

5. What percentage of your time is assigned to collection development?

6. What percentage of your time do you estimate you actually spend on collection development during the course of a year? 
Please respond to the following statements using the scale:

1. Strongly agree 2. Agree 3. Disagree 4. Strongly disagree

7. I have time to fulfill my collection development responsibilities.

8. I defer collection development responsibilities to other professional activities.

9. Faculty respect my professional qualifications and have confidence in my ability to select materials.

10. Faculty have confidence in my ability to weed materials from the collection.

11. I need more formal study in order to do a satisfactory job of collection development.

12. The organizational structure of my library supports and rewards collection development activities.

13: Iisted below are sixteen collection development activities. Please check the ones you think you should do or would like to do, and the ones you actually did in the past twelve months.

Should do Did

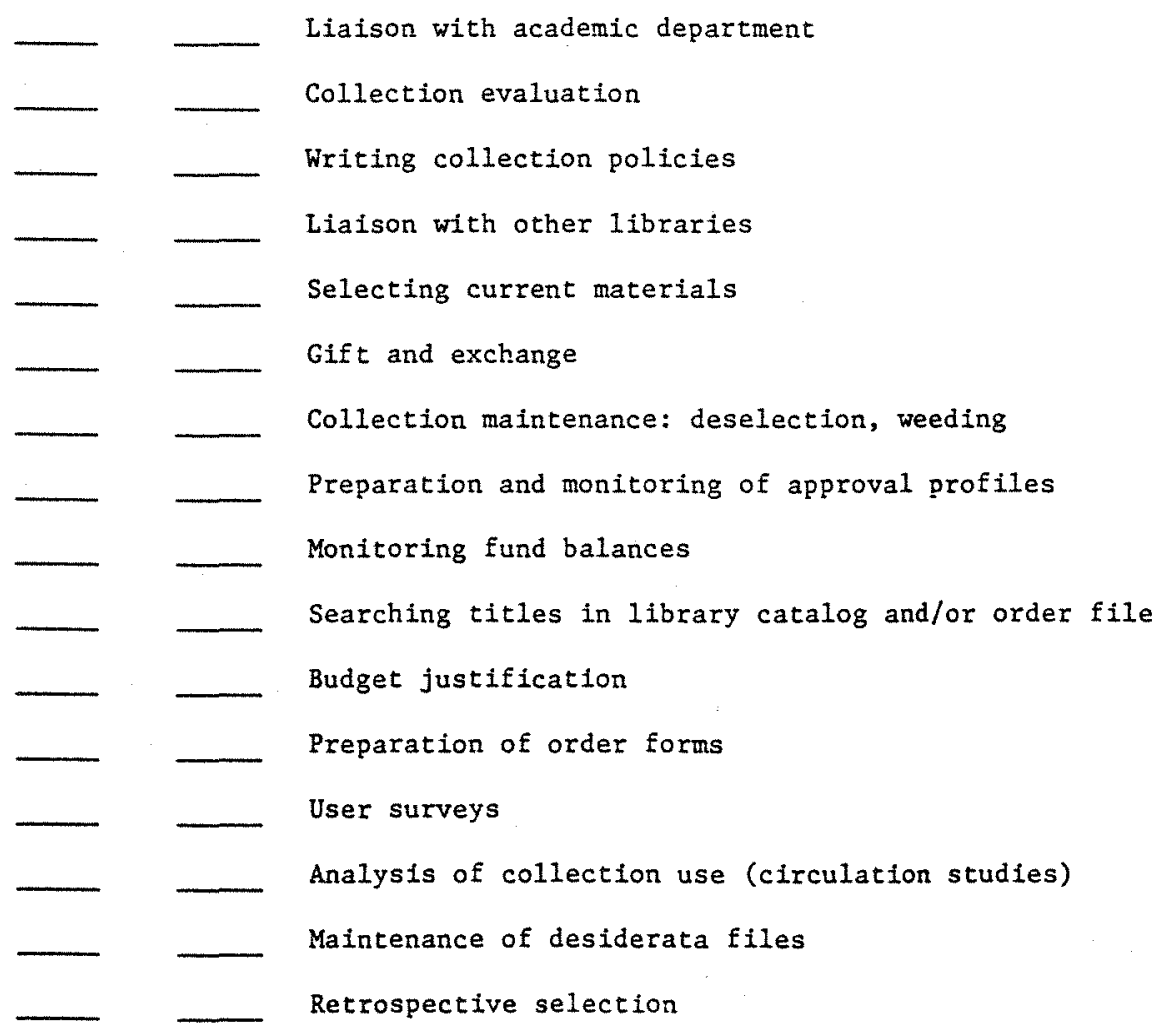




\section{APPENDIX D}

\section{IIBRARIANS JOB WITIES}

Type of Library Not Identified

Acquisitions Librarian

Archivist/Librarian

Associate Director of Libraries

Assistant Head, Reader Services Department

Cataloguer

Head of Acquisitions

Head of Bibliographic Control.

Head Reference Librarian

Reference Librarian, online searcher

Type 1 Libraries

Art Librarian

Assistant Acquisitions Librarian

Assistant Serials Librarian

Business/Reference Librarian

Catalog Librarian

Chair, Science Reference Division

Chairman, Humanities Reference Department 
Chair of Collection Development and Head of Acquisitions

Chief Cataloger

Coordinator - Downtown Library

Coordinator of Reader services

Head. Access Services (2)

Head, Acquisitions

Head, Cataloging

Head, Design and Planning Library

Head, Documents and Maps Department

Head, Documents/Special Collections

Head, Education/Psychology Department

Head, General \& Social Science Reference Division

Head, Information Services (Reference)

Head, Online Search Services and

Reference-Bibliographer

Head. Sciences \& Engineering Center/Sciences and Engineering Librarian

Head, Science Library

Head, Social Science Divisional Library

Head, Special Collections and Archives 
Head, Technical Services

Humanities Librarian

Library \& Information Science Librarian/Campus

Libraries Coordinator

Periodicals Librarian

Reference Librarian (11)

Reference Librarian/Bibliographer

Reference Librarian/Bibliographer Science \& Engineering

Reference Librarian/Science Librarian

Reference/Bibliographer Social sciences

Reference/Music Librarian

Reference/Special Collections Iibrarian

Science Librarian

Science Reference Librarian

Serials Librarian

Social Science Librarian/Documents Librarian

Social Science Reference/Bibliography and Chair of the Social Science Reference Department 
Type 2 Libraries

Art Bibliographer, Slide Librarian

Collection Development Librarian

General Services

Humanities Reference Bibliographer

Reference Bibliographer for Education

Reference Bibliographer for Science and Engineering

Science Bibliographer

Social Science Bibliographer

Social Sciences Reference Bibliographer

Subject Bibliographer

Type 3 Libraries

Assistant Director for Public Services

Assistant Reference Librarian

Assistant Head of Reference

Assistant to Head of Collection Development

AV Cataloger

Business Librarian

Business Reference Librarian

Catalog Librarian

Chief Reference Librarian 
Children's Literature Specialist

Collection Development Assistant

Collection Development Librarian

Coordinator of Computer Information Service

Coordinator of Library Instruction

Coordinator of Reference Services

Curator of Rare Books

Curator of Special Collections

Dean of Libraries

Director, Division of Theological Services

Documents Librarian

Documents/Special Collections Librarian

Engineering Reference Librarian

Fine Arts Reference \& Collection Development Librarian

General Reference/Collection Development for Science

Government Documents Librarian

Government Documents/Reference Librarian

Head of Acquisitions Department

Head of Audiovisual Department

Head of Circulation

Head of Documents/NC Collection 
Head of Information Services

Head of Lending Services (Circulation)

Head of Monographic Cataloging

Head of Music Library

Head of Public Access

Head of Reference (3)

Head Resource Management (Acquisitions)

Head of the Science Library

Head of Serials

Head, Special Collections

Humanities Bibliographer \& Reference Iibrarian

Humanities/Social Sciences Librarian (2)

Law Enforcement Librarian

Librarian - Geophysical Institute

Music Librarian (2)

OCLC Coordinator

Public Services Director

Public Services Librarian

Reference Librarian (17)

Reference Librarian and Coordinator of Library Instruction 
Reference Librarian/Coordinator of online Services Reference Librarian/Coordinator of Reference Collection Development

Reference Librarian/Head of Online Services Reference Serials Librarian/Health Services Librarian/Coordinator Periodicals Collection Reference/Bibliographer (2) Reference/Collection Development Librarian Reference/Curriculum Librarian Science Reference/Collection Development Librarian Serials Librarian

Social Sciences Reference/Collection Development Librarian

Social Work Librarian 
BIOGRAPHICAL SKETCH OF THE AUTHOR

Carol W. Cubberley was born and raised in Miami. Florida. She received a Bachelor's Degree in Education in 1969 from the University of Miami, and taught English to tenth graders at Homestead Senior High School for two years. Her career goal however. had always been to work as an academic librarian, and in 1973 she completed the degree Master of Science in Library Science at Florida state University.

The next ten years were spent at The University of the South in Sewanee. Tennessee. There Cubberley started as a catalog librarian and was promoted to the position Coordinator of Technical Services. During her time there, she functioned as a member of the Iibrary administrative team, and planned and supervised a move and rearrangement of the collection. She also participated in the installation of the OCLC system in the library, an automated acquisitions system, and the development of a collection development policy. Cubberley returned to her home state in 1983 . 
accepting the position Head of Acquisitions and Collection Development at the library of the University of Central Florida located in Orlando. There she installed an automated acquisitions system, chaired a committee that produced a collection development policy, and presided over a dramatic increase in funds available for library materials. She has been active in campus, state, and national organizations.

Cubberley lives with her husband in the small community of Chuluota, northeast of the UCF campus. Their interests are gardening and travel. They are in the process of building a laboratory for plant tissue culture, where they will produce grapes developed for Florida conditions. Their children live in Florida and Tennessee, and they have three granddaughters. 